\section{AN ANALYSIS OF THE BORSA ISTANBUL MANUFACTURING COMPANIES ON THE KEY AUDIT MATTERS ${ }^{1}$}

\author{
Kafkas University \\ Economics and Administrative \\ Sciences Faculty \\ KAUJEASF \\ Article Submission Date: 09.08.2021 \\ Accepted Date: 11.10.2021 \\ Vol. 12, Issue 24,2021 \\ ISSN: $1309-4289$ \\ E - ISSN: 2149-9136
}

\begin{abstract}
I The key audit
matters (KAM) have been included in the independent audit process recently and are recognized as an application to make the independent audit process more effective. Above all, the global financial crises experienced, and the complex nature of the financial transactions have revealed new quests in the audit process. In this context, the International Auditing and Assurance Standards Board (IAASB) published the "Communicating Key Audit Matters in the Independent Auditor's Report" (ISA 701) standard to make the independent audit process more efficient and meet the expectations of the stakeholders. By this article, the Public Oversight, Accounting and Auditing Standards Authority has published the independent audit standard 701, which includes the communicating of key audit matters in the independent auditor's statement. With the publication of the standart, identifying key audit matters in the audit process and specifying them in statements has also started. In this study, the audit reports (key audit matters) prepared by independent audit firms since 2017 when the mentioned standard came into force were analyzed within a three-year process, unlike previous academic studies in the BIST Manufacturing sector. In this respect, the study has addressed the development of key audit matters over three years and comparatively analyzed the change/transformation of key audit subjects in independent audit statements over the years on a company basis.
\end{abstract}

Keywords: Audit report, key audit matters, international standards on auditing Jel codes: M41, M42, M49

Scope: Business

Type: Research

DOI: $10.36543 /$ kauiibfd.2021.031

Cite this Paper: Tazegül, A. (2021). An analysis of the Borsa Istanbul manufacturing companies on the key audit matters. KAUJEASF, 12(24), 753-780.

\footnotetext{
${ }^{1}$ This manuscript has been prepared and submitted in accordance with the ethical rules.
} 


\section{BORSA ÍSTANBUL IMMALAT ŞIRKETLERININ KILIT DENETIM KONULARINA İLIŞKİN ANALIZi}

Makale Gönderim Tarihi: 09.08.2021

\section{Alper TAZEGÜL}

Doç. Dr.

Kafkas Üniversitesi

İktisadi ve İdari Bilimler Fakültesi,

Kars, Türkiye

alper.tazegul2004@gmail.com

ORCID ID: 0000-0001-8658-3814

Yayına Kabul Tarihi: 11.10.2021

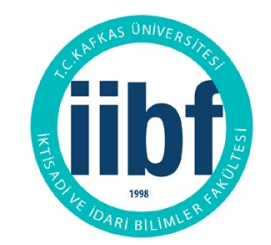

Kafkas Üniversitesi Íktisadi ve İdari Bilimle Fakültesi KAÜIİBFD

Cilt, 12, Say1 24, 2021

ISSN: $1309-4289$

E - ISSN: 2149-9136

O7| Kilit denetim konuları bağımsız denetim sürecine yakın zamanda dahil olan konulardan biri olup bağımsız denetim sürecini daha etkili kılmaya yönelik bir uygulama olarak kabul edilmektedir. Özellikle dünya genelinde yaşanan finansal krizler ve finansal işlemlerin doğası gereği karmaşık yapısı denetim sürecinde yeni arayışları ortaya çıkarmıştır. Bu kapsamda bağımsız denetim sürecinin daha verimli olması ve tarafların beklentilerini karşılayabilmesi için Uluslararası Denetim ve Güvence Standartları Kurulu (IAASB), "Kilit Denetim Konularının Bağımsız Denetçi Raporunda Bildirilmesi” (ISA 701) standardını yayımlamıştır. Bu standarda paralel olarak Kamu Gözetimi Muhasebe ve Denetim Standartları Kurumu tarafından kilit denetim konularının bağımsız denetçi raporunda bildirilmesi içeren bağımsız denetim standard 1 701'i yayınlamıştır. Standardın yayınlanması ile denetim sürecinde kilit denetim konularının belirlenmesi ve raporlarda belirtilmesi süreci de başlamıștır. Söz konusu standardın yürürlüğe girdiği 2017 yılından itibaren bağımsız denetim firmalarınca oluşturulan denetim raporları (kilit denetim konuları) Borsa İstanbul İmalat sektörü özelinde daha önce yapılan akademik çalışmalardan farklı olarak üç yıllık bir süreç dahilinde analiz edilmiştir. $\mathrm{Bu}$ yönüyle çalışma hem kilit denetim konularının üç yıllık periyotta gelişim durumunu ele almış hem de firma bazında üç yıllık süreçte kilit denetim konularının bağımsız denetim raporlarındaki y1llar içerisindeki değişimini/dönüşümünü karşılaştırmalı olarak analiz etmiştir.

Anahtar Kelimeler: Bağımsız denetim, yeni denetim raporlarl, kilit denetim konularl JEL Kodu: M41, M42, M49

Alan: İşletme

Türü: Araştırma 


\section{INTRODUCTION}

The independent auditor's main goal is to collect sufficient and appropriate evidence to provide a reasonable assurance in order to establish an opinion and to provide information to stakeholders. (PCAOB, 1972) Audit reports prepared in this context is a process output, and its structure and format have not changed in Turkey for many years. (Doğan, 2018, p. 66) Global crises, frauds, scandals, and other financial developments have made it inevitable that the audit matter changes in content and form. This change was initiated by the International Auditing and Assurance Standards Board and has been adopted in many countries. Turkey has also been one of the countries to adapt to these changes.

The efficiency and reliability of the independent audit will enhance the reliability of the financial information/reports provided by the management of the company. Only accuracy and effectiveness of the audit reports will meet the assurance expected from the stakeholders on this knowledge provided by the business administration (Karaca and Uygun 2016, p. 33) The International Auditing and Assurance Standards Board has published the standard on the key audit matters to increase the reliability of audit reports and make them more transparent and explanatory. This standard requires the auditor to disclose the most significant issues in the auditing process in the audit report (İşseveroğlu, 2019 , p. 50)

The change experienced by the audit process at both international and national levels has been discussed with this study and the key audit matters for companies operating in the Borsa Istanbul manufacturing industry have been examined comparatively over a three-year period since 2017 when key audit matters began to be included in independent audit reports.

\section{KEY AUDIT MATTERS}

The audit aims to increase confidence in financial statements (Şen, 2003, p. 2) with the realization of the audit, stakeholders will reach transparent and reliable reports. Although there is no debate about the necessity and usefulness of auditing at all levels, there is always a need and expectation for innovation regarding the implementation process and communicating.

This need has increased even more with the developments in recent years. As a result of the studies conducted in this context, the International Auditing and Assurance Standards Board has published the standard for key audit matters. The standard aims to raise the value of the inspection report by ensuring the transparency of the audit process.

Key audit matters can be defined as the communicating of important issues that the auditors pay attention to in the audit process according to their 
professional judgment (Bedard et al., 2014, p. 6) While determining these issues, the following items are taken into consideration (BDS 701, p. 9);

- Areas considered to be at higher risk of "material misstatement" or identified as being at serious risk by ISA 315 (section A19 - A22)

- Significant auditor judgments regarding areas of financial statements that involve significant management judgments, including accounting estimates determined to have high estimation uncertainty (section A23 - A24)

- The effects on the audit of significant events or transactions occurring during the period (section A25 - A26)

Key audit matters cover the significant issues that the independent auditor presents to the company's top management according to her/his professional experience and within the scope of the topics determined in the standards. These issues/findings may differ from business to business (Sayar and Ergüden, 2016, p. 95) The inclusion of key audit matters in the auditor's report will provide more specific information about potential risk issues to especially non-professional investors (Teraman and Çelik, 2019, p. 52)

Before the key audit standard implementation in Turkey, the auditor's inspections did not contain explanatory information on significant matters. With the inclusion of the key audit matters in the reports, key issues specific to the business began to be included in the statements under separate headings. In this way, users benefiting from financial statements have the opportunity to make more accurate investment decisions.

The International Audit and Assurance Standards Board listed the benefits of including key audit matters in independent audit reports as follows (Biçer and Erol, 2017, p. 75);

- Increasing the value of the report in the eye of the users by providing more transparency regarding the audit process,

- Revealing the points that investors and other information users focus on by including key audit matters to the report,

- Ability to establish a closer relationship with the users of the audit report findings and with the company management through key audit matters,

- Improving the relationship between the auditor and the audit commission,

- Occupational skepticism of the independent auditor may affect the audit quality by including key audit matters in the report.

The risk that the key audit matters' inclusion in the auditor's reports can create pressure on the auditor should not be overlooked (Dow, 2014; as cited in 
Teraman, and Çelik, 2019) Besides, the disclosure risk of company information that may be inconvenient to divulgence should also be considered.

Key audit matters should be under a separate heading in the reports, and the explanation related to each KAM should be prepared in such a way to refer to the explanations in the financial statements (Uzay and Köylü, 2018, p. 50) A key audit matter notification sample included in the audit reports and evaluated in this study is shown in Table 1.

Table 1. A Sample Key Audit Matter Statement

\begin{tabular}{|c|c|}
\hline Key Audit Matter & $\begin{array}{l}\text { The way this issue was addressed in the } \\
\text { audit }\end{array}$ \\
\hline $\begin{array}{l}\text { Impairment Testing of Goodwill and Intangible } \\
\text { Assets with Indefinite Lives } \\
\text { Anadolu Efes Biractllk ve Malt Sanayii A.Ş. } \\
\text { ("Anadolu Efes") and its subsidiary, Coca-Cola } \\
\text { İcecek A.Ş. ("Coca-Cola"), has expanded their } \\
\text { operations with business mergers. As a result of the } \\
\text { business combinations, the share of goodwill and } \\
\text { intangible assets of Anadolu Efes in its total assets } \\
\text { has reached } 42 \% \text { in the consolidated financial } \\
\text { statements. The Group management performs } \\
\text { annual impairment testing of its cash-generating } \\
\text { units to which goodwill has been allocated and its } \\
\text { intangible assets with indefinite lives by its } \\
\text { accounting policies. The recoverable amount of } \\
\text { cash-generating sections and intangible assets with } \\
\text { infinite lives is determined based on the value in use. } \\
\text { Recoverable amount is determined based on } \\
\text { discounted projected cash flows using significant } \\
\text { management estimates, such as revenue increase, } \\
\text { the weighted average cost of capital, discount rate, } \\
\text { long-term growth rate, and inflation rate. There are } \\
\text { substantial estimates and assumptions used in the } \\
\text { impairment tests performed by the Group } \\
\text { management and these assets have material } \\
\text { magnitude on the consolidated financial statements, } \\
\text { so the impairment testing of goodwill and intangible } \\
\text { assets with infinite lives is determined as a key audit } \\
\text { matter. The related disclosures containing the } \\
\text { accounting policies for impairment testing of } \\
\text { goodwill and intangible assets with indefinite lives } \\
\text { are disclosed in Notes } 2 \text { and } 17 \text {. }\end{array}$ & $\begin{array}{l}\text { The audit procedures performed include } \\
\text { but are not limited to the followings: • } \\
\text { Evaluating the appropriateness of cash- } \\
\text { generating units determined by Group } \\
\text { management, • Evaluating the Group's } \\
\text { budget processes in details (the basis of } \\
\text { estimations) and testing of principle and } \\
\text { arithmetical accuracy of models used for } \\
\text { discounted projected cash flows, } \\
\text { Evaluating forecasted cash flows for } \\
\text { each cash-generating unit comparing } \\
\text { with its prior year's financial } \\
\text { performances, } \text { - Through the } \\
\text { involvement of our internal valuation } \\
\text { specialists, assessing the reasonableness } \\
\text { of key assumptions used in each cash- } \\
\text { generating unit, including earnings } \\
\text { before interest, tax, depreciation and } \\
\text { amortization ("EBITDA"), long term } \\
\text { growth rates and discount rates, } \\
\text { - Comparative analysis of actual results } \\
\text { with the initial estimations to verify the } \\
\text { accuracy of historical assumptions, } \\
\text { Evaluating the sensitivity of the results to } \\
\text { the changes that may occur in the basic } \\
\text { assumptions in the impairment tests } \\
\text { carried out by the management, } \\
\text { Evaluating the appropriateness of } \\
\text { related disclosures regarding Intangible } \\
\text { Assets with Indefinite Lives and } \\
\text { Goodwill in Notes } 17 \text { per TFRS. }\end{array}$ \\
\hline
\end{tabular}

Source: Anadolu Efes Biracılık ve Malt Sanayii A.Ş. Independent Audit Report for year 2019. 
There is no standard pattern to follow when drafting key audit matters by the auditor. As in the example above, the auditor includes issues he appreciates as significant in this report under the content of the independent audit standard.

In exceptional cases where the legislation does not allow the matter to be disclosed to the public or it is reasonably expected that the adverse consequences of the public disclosure will exceed the public interest of the disclosure, the auditor may decide not to communicate the matter in the auditor's report (ISA 701, par. 37) 


\section{LITERATURE SUMMARY}

\begin{tabular}{|c|c|c|c|c|}
\hline $\begin{array}{l}\text { Researche } \\
\text { rs }\end{array}$ & $\begin{array}{l}\text { Rele } \\
\text { ase } \\
\text { Date }\end{array}$ & Headline & $\begin{array}{l}\text { Public } \\
\text { ation } \\
\text { Type }\end{array}$ & Content/Conclusion \\
\hline $\begin{array}{l}\text { Biçer, A. A. } \\
\text { Erol, S. }\end{array}$ & 2017 & $\begin{array}{l}\text { Communicating } \\
\text { Key Audit Matters } \\
\text { Identified During } \\
\text { Audit Process to } \\
\text { Financial } \\
\text { Information Users } \\
\text { in Accordance } \\
\text { With ISA } 701\end{array}$ & Article & $\begin{array}{l}\text { This study aims to define the auditors' } \\
\text { professional judgment process from } \\
\text { determining the key audit matters up } \\
\text { to the communicating of appropriate } \\
\text { information that needs to be explained } \\
\text { in the context of ISA } 701 \text {. }\end{array}$ \\
\hline Doğan, A. & 2018 & $\begin{array}{l}\text { A New Approach } \\
\text { In Auditing: Key } \\
\text { Audit Matters }\end{array}$ & Article & $\begin{array}{l}\text { The article examines how to determine } \\
\text { key audit matters in accordance with } \\
\text { the new audit standard ISA/BDS } 701 \\
\text { and how these issues will be } \\
\text { communicated in the independent } \\
\text { audit report. }\end{array}$ \\
\hline Gökgöz, A. & 2018 & $\begin{array}{l}\text { Communicating } \\
\text { Key Audit Matters } \\
\text { within the } \\
\text { Independent } \\
\text { Audit's Report and } \\
\text { A Study on The } \\
\text { Companies Listed } \\
\text { in Borsa İstanbul }\end{array}$ & Article & $\begin{array}{l}\text { The study examined the audit reports } \\
\text { of } 140 \text { companies registered in BIST } \\
\text { for the fiscal year } 2017 \text { and made } \\
\text { qualitative and quantitative analyzes } \\
\text { within the scope of key audit matters. } \\
\text { It has been determined that the key } \\
\text { audit matters primarily include } \\
\text { revenue, trade receivables, } \\
\text { inventories, tangible assets, and } \\
\text { investment properties, respectively. }\end{array}$ \\
\hline $\begin{array}{l}\text { Kavut, F. } \\
\text { L. } \\
\text { Güngör, N. }\end{array}$ & 2018 & $\begin{array}{l}\text { Key audit matters } \\
\text { in Independent } \\
\text { Auditing: } 2017 \\
\text { Analysis of BIST- } \\
100 \text { Companies }\end{array}$ & Article & $\begin{array}{l}\text { In the study, content analysis of key } \\
\text { audit matters included in the } \\
\text { independent audit reports of BIST- } 100 \\
\text { companies in } 2017 \text { was conducted. As } \\
\text { a result, the study determined that } \\
\text { companies operating in the same } \\
\text { sector attach importance to particular } \\
\text { subjects and the auditors find similar } \\
\text { issues significant in the sectoral field. }\end{array}$ \\
\hline $\begin{array}{l}\text { Çağıran } \\
\text { Kalıpçı, F. } \\
\text { Varıcı, I. }\end{array}$ & 2018 & $\begin{array}{l}\text { Key audit matters } \\
\text { within the } \\
\text { Framework of } \\
\text { Independent } \\
\text { Auditing Standard } \\
\text { (ISA) 701: An } \\
\text { Analysis on Audit }\end{array}$ & Article & $\begin{array}{l}\text { This study aims to conduct the content } \\
\text { analysis of the enterprises registered in } \\
\text { the manufacturing sector of the BIST } \\
\text { per } 2017 \text { audit reports data. }\end{array}$ \\
\hline
\end{tabular}


KAUJEASF 12(24), 2021: 753-780

\begin{tabular}{|c|c|c|c|c|}
\hline & & $\begin{array}{l}\text { Reports of } \\
\text { Enterprises in } \\
\text { Borsa Istanbul } \\
\text { Manufacturing } \\
\text { Industry Sector }\end{array}$ & & \\
\hline $\begin{array}{l}\text { Karacan, S. } \\
\text { Uygun, R. }\end{array}$ & 2018 & $\begin{array}{l}\text { Communicating } \\
\text { Key Audit Matters } \\
\text { in the Independent } \\
\text { Auditor's Report - } \\
\text { ISA } 701\end{array}$ & Article & $\begin{array}{l}\text { The research intends to evaluate the } \\
\text { auditing reports of } 62 \text { companies } \\
\text { operating in the real sector and traded } \\
\text { in BIST. In the study, financial } \\
\text { statement users demand the auditors } \\
\text { not only to express their opinions, but } \\
\text { also prepare business-specific reports } \\
\text { without adhering to standard patterns } \\
\text { and provide more explanatory and } \\
\text { specific information on the company. }\end{array}$ \\
\hline $\begin{array}{l}\text { Oktay, S. } \\
\text { Bozkurt, S. } \\
\text { Şahin, B. Ş. }\end{array}$ & 2018 & $\begin{array}{l}\text { Investigation of } \\
\text { Studies in the Field } \\
\text { of Key Audit } \\
\text { Matters by Content } \\
\text { Analysis }\end{array}$ & Article & $\begin{array}{l}\text { This study carried out the content } \\
\text { analysis to define the direction of the } \\
\text { research performed on the field of the } \\
\text { key audit matters and to raise } \\
\text { awareness for further studies. For this } \\
\text { purpose, the articles published in } \\
\text { Ebsco, Wiley, Jstor, and Google } \\
\text { Scholar databases were examined. The } \\
\text { study evaluated the papers in the } \\
\text { relevant databases in terms of the } \\
\text { author, journal name, year, research } \\
\text { methodology, data collection tools and } \\
\text { techniques, sample, and related topics. }\end{array}$ \\
\hline $\begin{array}{l}\text { Uzay, Ş. } \\
\text { Köylü, Ç. }\end{array}$ & 2018 & $\begin{array}{l}\text { Key Audit Matters: } \\
\text { A Study on Borsa } \\
\text { Istanbul }\end{array}$ & Article & $\begin{array}{l}\text { The study, aiming to determine the } \\
\text { key audit matters the auditors attach } \\
\text { importance to during the audit process } \\
\text { using the content analysis method, was } \\
\text { conducted on } 181 \text { businesses } \\
\text { registered in the BIST manufacturing } \\
\text { sector. Independent audit reports of } \\
170 \text { companies were examined in the } \\
\text { study, and } 354 \text { key audit subjects were } \\
\text { declared. }\end{array}$ \\
\hline Velte, P. & 2018 & $\begin{array}{l}\text { Does Gender } \\
\text { Diversity in the } \\
\text { Audit Committee } \\
\text { Influence Key } \\
\text { Audit Matters' } \\
\text { Readability in the } \\
\text { Audit Report? UK } \\
\text { Evidence. }\end{array}$ & Article & $\begin{array}{l}\text { This paper investigates the } \\
\text { relationship between the percentage of } \\
\text { women on audit committees (WOAC) } \\
\text { in UK firms and the auditors' } \\
\text { disclosures on key audit matters } \\
\text { (KAM) from } 2014 \text { to } 2015 \text {. The results } \\
\text { show that firms with a higher } \\
\text { percentage of WOAC have higher } \\
\text { readability of KAM disclosures }\end{array}$ \\
\hline Altawalbeh & 2019 & Investors & Article & The purpose of this article is to explore \\
\hline
\end{tabular}


KAUJEASF 12(24), 2021: 753-780

\begin{tabular}{|c|c|c|c|c|}
\hline $\begin{array}{l}\text { M. A.F. } \\
\text { Alhajaya, } \\
\text { M. E. S. }\end{array}$ & & $\begin{array}{l}\text { Reaction to the } \\
\text { Disclosure of Key } \\
\text { Audit Matters: } \\
\text { Empirical } \\
\text { Evidence from } \\
\text { Jordan }\end{array}$ & & $\begin{array}{l}\text { the impact of disclosure of key audit } \\
\text { matters on investors' decisions. For } \\
\text { this aim, the study examined the } \\
\text { Jordanian market responses to the } \\
\text { statements of key audit matters. The } \\
\text { results show that the Jordanian market } \\
\text { reacts differently. }\end{array}$ \\
\hline $\begin{array}{l}\text { Asbahr, K. } \\
\text { Ruhnke, K. }\end{array}$ & 2019 & $\begin{array}{l}\text { Real Effects of } \\
\text { Reporting Key } \\
\text { Audit Matters on } \\
\text { Auditors' } \\
\text { Judgment and } \\
\text { Choice of Action }\end{array}$ & Article & $\begin{array}{l}\text { This experimental study aims to } \\
\text { analyze whether communicating an } \\
\text { accounting estimate as a key audit } \\
\text { matter (KAM) can influence auditor } \\
\text { judgment about the accounting } \\
\text { estimate and the corresponding action. }\end{array}$ \\
\hline $\begin{array}{l}\text { Ciğer, A. } \\
\text { Vardar, G. } \\
\text { Ç. } \\
\text { Kinay, B. }\end{array}$ & 2019 & $\begin{array}{l}\text { Key Audit Matters: } \\
\text { A Research on } \\
\text { Listed Firms in } \\
\text { CEE Countries and } \\
\text { Turkey }\end{array}$ & Article & $\begin{array}{l}\text { This study aims to identify and } \\
\text { analyze the most significant matters } \\
\text { (key audit matters) in auditing } \\
\text { highlighted in auditors' reports of } \\
\text { companies in the manufacturing sector } \\
\text { and to determine whether there is a } \\
\text { divergence or convergence between } \\
\text { the CEE countries and Turkey. }\end{array}$ \\
\hline $\begin{array}{l}\text { Ciğer, A. } \\
\text { Vardar, G. } \\
\text { Ç. } \\
\text { Kinay, B. }\end{array}$ & 2019 & $\begin{array}{l}\text { Analysis of Key } \\
\text { Audit Matters in } \\
\text { Independent } \\
\text { Auditor Reports: } \\
\text { Borsa Istanbul } \\
\text { Example }\end{array}$ & Article & $\begin{array}{l}\text { Based on the data in the auditor's } \\
\text { reports between } 2009 \text { and } 2017 \text {, the } \\
\text { article obtained information on the } \\
\text { following subjects of } 500 \text { companies } \\
\text { in the BIST: the number of key audit } \\
\text { subjects, the duration of work with the } \\
\text { current audit firm, the number of } \\
\text { different audits the companies worked } \\
\text { with, the financial statement } \\
\text { presentation type, types of opinions, } \\
\text { previous working times and audit } \\
\text { network with the current audit firm. } \\
\text { The study aims to perform a frequency } \\
\text { analysis of key audit matters by } \\
\text { industry and audit firms. }\end{array}$ \\
\hline $\begin{array}{l}\text { Çağıran } \\
\text { Kalıpçı, F. }\end{array}$ & 2019 & $\begin{array}{l}\text { Analysis of Key } \\
\text { Audit Matters in } \\
\text { the Context of } \\
\text { Countries under } \\
\text { ISA 701 }\end{array}$ & Article & $\begin{array}{l}\text { The study aims to explain the ISA } 701 \\
\text { key audit matters within the scope of } \\
\text { the independent auditor standard by } \\
\text { including examples from audit reports } \\
\text { on key audit matters of enterprises in } \\
\text { different countries. }\end{array}$ \\
\hline $\begin{array}{l}\text { Ertan, Y. } \\
\text { Kızı, E. }\end{array}$ & 2019 & $\begin{array}{l}\text { Key Audit Matters: } \\
\text { Examination of } \\
2017 \text { Audit Reports } \\
\text { of Enterprises } \\
\text { Operating in the } \\
\text { BIST }\end{array}$ & Article & $\begin{array}{l}\text { The article covered } 177 \text { businesses } \\
\text { registered in the BIST manufacturing } \\
\text { industry to examine the key audit } \\
\text { matters included in the audit report. } \\
\text { The study assesses the first } \\
\text { applications of KAM in terms of the }\end{array}$ \\
\hline
\end{tabular}




\begin{tabular}{|c|c|c|c|c|}
\hline & & $\begin{array}{l}\text { Manufacturing } \\
\text { Sector }\end{array}$ & & $\begin{array}{l}\text { manufacturing sector, sub-sectors of } \\
\text { the manufacturing industry, and audit } \\
\text { firms. }\end{array}$ \\
\hline $\begin{array}{l}\text { Sierra- } \\
\text { Garcia, L. } \\
\text { Gambetta, } \\
\text { N. } \\
\text { Garcia- } \\
\text { Benau, M. } \\
\text { A. } \\
\text { Orta-Perez, } \\
\text { M. }\end{array}$ & 2019 & $\begin{array}{l}\text { Understanding the } \\
\text { Determinants of } \\
\text { the Magnitude of } \\
\text { Entity-Level Risk } \\
\text { and Account-Level } \\
\text { Risk Key Audit } \\
\text { Matters: The Case } \\
\text { of the United } \\
\text { Kingdom }\end{array}$ & Article & $\begin{array}{l}\text { This study analyzed the influence of } \\
\text { auditor and client characteristics on } \\
\text { the magnitude and type of key audit } \\
\text { matters (KAM) disclosed in the audit } \\
\text { reports of the FTSE } 100 \text { companies in } \\
\text { the UK during the period 2013-2016. }\end{array}$ \\
\hline $\begin{array}{l}\text { Gönen, S. } \\
\text { Yıldırım, F. }\end{array}$ & 2019 & $\begin{array}{lr}\text { ISA 701 Key Audit } \\
\text { Matters: } & \text { An } \\
\text { Analysis of BIST } \\
\text { Banks } & \text { and } \\
\text { Insurance } & \\
\text { Companies } & \end{array}$ & $\begin{array}{l}\text { Declar } \\
\text { ation }\end{array}$ & $\begin{array}{l}\text { After examining the ISA } 701 \text { key audit } \\
\text { matters standard, it was aimed to } \\
\text { analyze inspecting the } 2017 \text { audit } \\
\text { reports for Banks and Private Finance } \\
\text { Institutions and Insurance companies } \\
\text { registered in BIST. The analysis } \\
\text { revealed that "Impairment of Loans } \\
\text { and Receivables" is the most } \\
\text { significant issue for auditors in banks } \\
\text { and private financial institutions as } \\
\text { "estimates and assumptions used for } \\
\text { the calculation of the technical } \\
\text { provisions of insurance" are } \\
\text { substantial for insurance companies. }\end{array}$ \\
\hline $\begin{array}{l}\text { İşseveroğlu } \\
\text {, G. }\end{array}$ & 2019 & $\begin{array}{l}\text { Key Audit Matters } \\
\text { In Independent } \\
\text { Audit Report: } \\
\text { Analysis } \quad \text { On } \\
\text { Insurance } \\
\text { Companies Listed } \\
\text { In The BIST In } \\
2017 \text { And 2018 }\end{array}$ & Article & $\begin{array}{l}\text { The article addresses the standard and } \\
\text { communicating of key audit matters } \\
\text { by carrying out content analysis for } \\
\text { insurance companies registered in } \\
\text { BIST regarding the importance and } \\
\text { explanations of key audit matters } \\
\text { included in the audit reports in 2017- } \\
2018 \text {. }\end{array}$ \\
\hline $\begin{array}{l}\text { Uzun } \\
\text { Kocamış, } \\
\text { T. } \\
\text { Yıldırım, } \\
\text { G. }\end{array}$ & 2019 & $\begin{array}{l}\text { Key Audit Matters } \\
\text { in the Independent } \\
\text { Auditor's Report: } \\
\text { Possible Effects }\end{array}$ & Article & $\begin{array}{l}\text { The article attempts to identify how } \\
\text { key audit matters are identified within } \\
\text { the scope of ISA } 701 \text { key audit } \\
\text { matters, what issues the auditor should } \\
\text { emphasize in the report, and their } \\
\text { possible effects. }\end{array}$ \\
\hline Sahyda, R. & 2019 & $\begin{array}{l}\text { Key Audit Matters } \\
\text { in Enhanced } \\
\text { Auditor's Report: } \\
\text { Tracing Malaysia } \\
\text { in Its First Year } \\
\text { Implementation }\end{array}$ & Article & $\begin{array}{l}\text { This study examines the key audit } \\
\text { matters included in the independent } \\
\text { auditor's report according to the } \\
\text { enhanced auditor reports, the latest } \\
\text { international auditing standards rule. }\end{array}$ \\
\hline Sarısoy, Ö. & 2019 & Including Key & Article & This research aimed to study the \\
\hline
\end{tabular}




\begin{tabular}{|c|c|c|c|c|}
\hline Kepçe, N. & & $\begin{array}{l}\text { Audit Matters in } \\
\text { the Independent } \\
\text { Audit Report and } \\
\text { Differences in } \\
\text { Expectations }\end{array}$ & & $\begin{array}{l}\text { opinions of the auditing report users } \\
\text { on the "Key Audit Matters" and the } \\
\text { independent audit statements exposed } \\
\text { to modifications. The study conducted } \\
\text { the Survey technique and evaluated } \\
\text { the data using the statistical technique. } \\
\text { The study determined a significant } \\
\text { expectation gap among the interest } \\
\text { groups regarding the key audit } \\
\text { matters. }\end{array}$ \\
\hline $\begin{array}{l}\text { Taş, O. } \\
\text { Mert, H. } \\
\text { Varcan } \\
\text { Başkaya, } \\
\text { A. }\end{array}$ & 2019 & $\begin{array}{l}\text { Key Audit Matters } \\
\text { in Independent } \\
\text { Audit Reports and } \\
\text { a Research on } \\
\text { Implementations }\end{array}$ & $\begin{array}{l}\text { Declar } \\
\text { ation }\end{array}$ & $\begin{array}{l}\text { From the data of } 2017 \text { and } 2018 \text { audit } \\
\text { reports, key audit matters of publicly } \\
\text { traded companies were analyzed and } \\
\text { interpreted by comparing them in } \\
\text { terms of scope and explanations. }\end{array}$ \\
\hline $\begin{array}{l}\text { Teraman, } \\
\text { Ö. } \\
\text { Çelik, B. }\end{array}$ & 2019 & $\begin{array}{l}\text { Reflecting Key } \\
\text { Audit Matters in } \\
\text { the Independent } \\
\text { Audit Report: A } \\
\text { Study on the Effect } \\
\text { of the Independent } \\
\text { Auditors }\end{array}$ & Article & $\begin{array}{l}\text { The study aimed to determine the } \\
\text { effects of } 701 \text { independent audit } \\
\text { standards on independent auditors } \\
\text { within the scope of qualitative } \\
\text { research. }\end{array}$ \\
\hline Segal, M. & 2019 & $\begin{array}{l}\text { Key Audit Matters: } \\
\text { Insight from Audit } \\
\text { Experts }\end{array}$ & Article & $\begin{array}{l}\text { The purpose of this study is to analyze } \\
\text { whether the latest regulation for the } \\
\text { auditors of companies registered BIST } \\
\text { on communicating key audit matters } \\
\text { in the auditing reports increased the } \\
\text { audit reports transparencies, what } \\
\text { additional risks they are currently } \\
\text { facing, how the risk is managed, and } \\
\text { its impact on customer relationships. }\end{array}$ \\
\hline $\begin{array}{l}\text { Aktaş, R. } \\
\text { Acar, M. }\end{array}$ & 2020 & $\begin{array}{l}\text { Critical Audit } \\
\text { Matters within the } \\
\text { Perspective of } \\
\text { Audit Materiality } \\
\text { Threshold: Borsa } \\
\text { İstanbul Case }\end{array}$ & Article & $\begin{array}{l}\text { The study examines key audit matters, } \\
\text { which started to be included in } \\
\text { independent audit reports in } 2017 \text { for } \\
\text { the first time, in the BIST } 100 \text { index } \\
\text { for the } 2017-2018 \text { period. KAM was } \\
\text { handled individually on a company } \\
\text { basis, and then grouping was made } \\
\text { between KAM and the account items } \\
\text { they relate to it. Addressing key audit } \\
\text { matters shaping the audit process in } \\
\text { terms of their materiality emphasizes } \\
\text { the study's uniqueness. }\end{array}$ \\
\hline $\begin{array}{l}\text { Arzova, S. } \\
\text { B. } \\
\text { Şahin, B. Ş. }\end{array}$ & 2020 & $\begin{array}{l}\text { ISA } 701 \text { (BDS 701) } \\
\text { Key Audit Matters: } \\
\text { Analysis r of } \\
\end{array}$ & Article & $\begin{array}{l}\text { The study made a content analysis of } \\
\text { the audit reports for the companies } \\
\text { operating in the financial services field }\end{array}$ \\
\hline
\end{tabular}




\begin{tabular}{|c|c|c|c|c|}
\hline & & 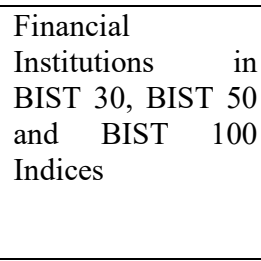 & & $\begin{array}{l}\text { in BIST } 30 \text {, BIST } 50 \text {, and BIST } 100 \text {. It } \\
\text { aimed to determine the significance } \\
\text { level between the relationship between } \\
\text { the KAM and the elements related to } \\
\text { the audit in these companies, and the } \\
\text { auditor's opinion, the audit firm, and } \\
\text { the number of pages. }\end{array}$ \\
\hline $\begin{array}{l}\text { Aytaç, A. } \\
\text { Gücenme } \\
\text { Gençoğlu, } \\
\text { Ü. }\end{array}$ & 2020 & $\begin{array}{l}\text { Key Audit Matters: } \\
\text { A Perpective Based } \\
\text { on Bibliometric } \\
\text { Analysis }\end{array}$ & Article & $\begin{array}{l}\text { This study aims to identify the } \\
\text { strategic scheme of key audit matters } \\
\text { and to see the longitudinal evolution of } \\
\text { key audit matters after the draft } \\
\text { published in 2013. }\end{array}$ \\
\hline $\begin{array}{l}\text { Gold, A. } \\
\text { Heilmann, } \\
\text { M. Pott, C. } \\
\text { Rematzki,J }\end{array}$ & 2020 & $\begin{array}{l}\text { Do Key Audit } \\
\text { Matters Impact } \\
\text { Financial Repoting } \\
\text { Beavior? }\end{array}$ & Article & $\begin{array}{l}\text { This study empirically examines } \\
\text { whether the application of key audit } \\
\text { matters in auditor reports affects the } \\
\text { communicating behavior of managers. }\end{array}$ \\
\hline $\begin{array}{l}\text { Keskin, D. } \\
\text { A. } \\
\text { Tutar, S. } \\
\text { Öktem, B. } \\
\text { Akçay, B. }\end{array}$ & 2020 & $\begin{array}{l}\text { The Effect of } \\
\text { Gender on The } \\
\text { Readability of Key } \\
\text { Audit Matters } \\
\text { According to ARI } \\
\text { Readability Index: } \\
\text { A Sectoral Review }\end{array}$ & Article & $\begin{array}{l}\text { The study aimed to examine the } \\
\text { readability of key audit subjects under } \\
\text { the ARI readability index according to } \\
\text { gender differences. The study } \\
\text { evaluated key audit matters in the } \\
\text { independent auditor reports published } \\
\text { in } 2018 \text { according to the readability } \\
\text { index of businesses operating in the } \\
\text { banking, manufacturing, and } \\
\text { telecommunications sectors. }\end{array}$ \\
\hline $\begin{array}{l}\text { Köhler, A. } \\
\text { Ratzinger- } \\
\text { Sakel, N. } \\
\text { Theis, J. }\end{array}$ & 2020 & $\begin{array}{l}\text { The Effects of Key } \\
\text { Audit Matters on } \\
\text { the Auditor's } \\
\text { Report's } \\
\text { Communicative } \\
\text { Value: } \\
\text { Experimental } \\
\text { Evidence from } \\
\text { Investment } \\
\text { Professionals and } \\
\text { Non-professional } \\
\text { Investors }\end{array}$ & Article & $\begin{array}{l}\text { They investigate the impact of key } \\
\text { audit matters (KAM) in the auditor's } \\
\text { report as required by the new ISA 701. } \\
\text { They consider investment } \\
\text { professionals and non-professional } \\
\text { investors in the experiments, in which } \\
\text { they test the communicative value of a } \\
\text { KAM section relating to goodwill } \\
\text { impairment. Their main results show } \\
\text { that if the KAM section suggests } \\
\text { that already small changes in the key } \\
\text { assumptions could eventually lead to a } \\
\text { goodwill impairment (KAM negative } \\
\text { condition), investment professionals } \\
\text { assess the economic situation of the } \\
\text { company to be significantly better in } \\
\text { comparison. }\end{array}$ \\
\hline Shao, X. & 2020 & $\begin{array}{l}\text { Research on } \\
\text { Disclosure Status } \\
\text { and Influencing } \\
\text { Factors of Key }\end{array}$ & Art & $\begin{array}{l}\text { This article mainly examines the } \\
\text { factors that influence key audit matters } \\
\text { in China. It quantifies the } \\
\text { characteristics of KAM and researches }\end{array}$ \\
\hline
\end{tabular}




\begin{tabular}{|l|l|l|l|l|}
\hline & & Audit Matters & $\begin{array}{l}\text { the impact on the disclosure of key } \\
\text { audit matters at two levels of the firm } \\
\text { and the auditor. }\end{array}$ \\
\hline $\begin{array}{l}\text { In, C. } \\
\text { Kim, T. } \\
\text { Park, S. }\end{array}$ & 2020 & $\begin{array}{l}\text { Key Audit Matters } \\
\text { for Production-To- } \\
\text { Order Industry and } \\
\text { Conservatism }\end{array}$ & Article & $\begin{array}{l}\text { In this study, the effects of key audit } \\
\text { matters (KAMs), one of the measures } \\
\text { recently introduced to improve } \\
\text { accounting transparency in the } \\
\text { production-to-order industry in terms } \\
\text { of corporate sustainability, are } \\
\text { examined. }\end{array}$ \\
\hline
\end{tabular}

\section{RESEARCH METHODOLOGY}

\subsection{Purpose}

In an environment where even small and medium-sized businesses open to international markets and cooperate with multinational organizations, it is an inevitable necessity for companies to have a more transparent and reliable legal and administrative structure. This situation becomes more significant, especially in public enterprises. That many investors have information about short or longterm business policies will enable them to participate more effectively in these investment decisions. In this context, key audit subjects included in the independent audit standard create a more transparent and reliable space for the stakeholders. This study aimed to evaluate three-year-period key audit matters specific to the Borsa İstanbul manufacturing sector.

\subsection{Scope-Limitations}

The study is limited to enterprises operating in the Borsa Istanbul manufacturing sector. These companies included key audit matters in their audit reports uninterruptedly in the 2017-2018-2019 periods. In this context, between the dates of 01.06.2020-31.06.2020 when the research data were collected, 126 companies were evaluated, which added key audit matters in their audit reports and opening their data to access via the website.

\subsection{Method}

In this study, the audit reports of companies in the Borsa Istanbul manufacturing sector, that include key audit matters in their statements for the full last three years, were examined using content analyses. Unlike previous studies, a single table includes the each enterprises's key audit matters data of three years in the audit reports of the companies. These periods are grouped and interpreted separately by years. Thus, the key audit changes/improvements in the statements within three years can be easily evaluated on an enterprise basis. The audit reports of the organizations can be found on the relevant company's website. 


\subsection{Findings}

Key audit matters of the enterprises evaluated in the study are grouped by years and given in Table 2. tangible fixed assets 
Table 2. Manufacturing Sector Key Audit Matters Frequency Analysis Between 2017 and 2019

\begin{tabular}{|c|c|c|c|}
\hline \multicolumn{4}{|c|}{ Grouped Key Audit Matters } \\
\hline $\begin{array}{l}\text { Company } \\
\text { Name }\end{array}$ & 2017 & 2018 & 2019 \\
\hline $\begin{array}{l}1-A V O D \\
\text { Kurutulmuş } \\
\text { Gıda }\end{array}$ & $\begin{array}{l}\text { *Tangible fixed assets } \\
\text { *Revaluation of real } \\
\text { estate } \\
\text { *Inventories }\end{array}$ & $\begin{array}{l}\text { *Trade Receivables } \\
\text { *Inventories } \\
\text { *Revenues }\end{array}$ & $\begin{array}{l}\text { *Trade Receivables } \\
* \text { Inventories } \\
\text { *Revenues } \\
\text { *Revaluation of real } \\
\text { estate }\end{array}$ \\
\hline 2- Aciselsan & $\begin{array}{l}\text { *Tangible fixed assets } \\
* \text { Revenues }\end{array}$ & $\begin{array}{l}\text { *Tangible fixed assets } \\
* \text { Revenues }\end{array}$ & $\begin{array}{l}\text { *Revaluation of real } \\
\text { estate }\end{array}$ \\
\hline $\begin{array}{l}\text { 3- Adana } \\
\text { Çimento }\end{array}$ & $\begin{array}{l}\text { *Revenues } \\
\text { *Impairment of shares } \\
\text { in associates }\end{array}$ & $\begin{array}{l}\text { *Revenues } \\
\text { *Impairment of shares } \\
\text { in associates }\end{array}$ & $\begin{array}{l}\text { *Revenues } \\
\text { *Impairment of shares } \\
\text { in associates }\end{array}$ \\
\hline $\begin{array}{l}\text { 4- Adel } \\
\text { Kalemcilik }\end{array}$ & *Sales discounts & $*$ Sales discounts & *Sales discounts \\
\hline $\begin{array}{l}\text { 5- Afyon } \\
\text { Çimento }\end{array}$ & $\begin{array}{l}\text { *Construction In } \\
\text { Progress } \\
\text { *Capitalization of } \\
\text { financing costs } \\
\text { *Income tax deduction }\end{array}$ & $\begin{array}{l}\text { *Depreciation } \\
\text { *Income tax deduction }\end{array}$ & $\begin{array}{l}\text { *Corporate tax } \\
\text { deduction }\end{array}$ \\
\hline $\begin{array}{l}\text { 6-Akın } \\
\text { tekstil }\end{array}$ & $\begin{array}{l}\text { *Trade Receivables } \\
\text { * Revaluation of real } \\
\text { estate } \\
\text { *Stock impairment }\end{array}$ & $\begin{array}{l}\text { *Trade Receivables } \\
\text { *Stock impairment } \\
\text { *Tangible fixed assets }\end{array}$ & $\begin{array}{l}\text { *Trade Receivables } \\
\text { *Stock impairment } \\
\text { *Tangible fixed assets } \\
\text { * Revaluation of real } \\
\text { estate }\end{array}$ \\
\hline $\begin{array}{l}\text { 7- Aksa } \\
\text { Akrilik }\end{array}$ & $\begin{array}{l}\text { *Trade receivables - } \\
\text { Impairment } \\
\text { *Corporate tax } \\
\text { calculation }\end{array}$ & $\begin{array}{l}\text { *Stock impairment } \\
\text { *Trade receivables - } \\
\text { Impairment }\end{array}$ & $\begin{array}{l}* \text { Stock impairment } \\
\text { *Trade receivables - } \\
\text { Impairment }\end{array}$ \\
\hline 8-Alarko & $\begin{array}{l}\text { *Revenue } \\
\text { *Inventories }\end{array}$ & $\begin{array}{l}\text { *Revaluation of real } \\
\text { estate } \\
\text { *Trade Patables } \\
\text { *Impairment }\end{array}$ & $\begin{array}{l}\text { *Revenue } \\
* \text { Revaluation of real } \\
\text { estate } \\
\text { *Impairment }\end{array}$ \\
\hline 9- Alkim & $\begin{array}{l}\text { * Recoverability of trade } \\
\text { receivables }\end{array}$ & $\begin{array}{l}* \text { Recoverability of } \\
\text { trade receivables }\end{array}$ & $\begin{array}{l}* \text { Recoverability of } \\
\text { trade receivables }\end{array}$ \\
\hline $\begin{array}{l}\text { 10- Anadolu } \\
\text { Cam }\end{array}$ & $\begin{array}{l}\text { *Tangible fixed assets } \\
\text { *Revenues }\end{array}$ & $\begin{array}{l}\text { *Hedge Accounting } \\
\text { *Deferred tax assets }\end{array}$ & $\begin{array}{l}\text { *Auditor transition } \\
\text { *Deferred tax assets } \\
\text { *Provisions for } \\
\text { Employee Benefits }\end{array}$ \\
\hline $\begin{array}{l}\text { 11- Anadolu } \\
\text { Isuzu }\end{array}$ & $\begin{array}{l}* \text { Sales discounts } \\
* \text { Tangible fixed assets }\end{array}$ & *Deferred tax assets & $*$ Deferred tax assets \\
\hline 12- Arçelik & $\begin{array}{l}\text { * Recoverability of trade } \\
\text { receivables } \\
\text { *Stock impairment }\end{array}$ & $\begin{array}{l}* \text { Recoverability of } \\
\text { trade receivables } \\
* \text { Stock impairment }\end{array}$ & $\begin{array}{l}* \text { Recoverability of } \\
\text { trade receivables } \\
* \text { Stock impairment }\end{array}$ \\
\hline
\end{tabular}


KAUJEASF 12(24), 2021: 753-780

\begin{tabular}{|c|c|c|c|}
\hline & $*$ Tangible fixed assets & $*$ Tangible fixed assets & $\begin{array}{l}\text { *Tangible fixed assets } \\
\text { *The Leases Standard }\end{array}$ \\
\hline $\begin{array}{l}\text { 13-Aslan } \\
\text { Çimento }\end{array}$ & $\begin{array}{l}\text { *Revenue } \\
\text { *Impairment of shares } \\
\text { in associates }\end{array}$ & $\begin{array}{l}\text { *Revenue } \\
\text { *Impairment of shares } \\
\text { in associates }\end{array}$ & $\begin{array}{l}\text { *Impairment of shares } \\
\text { in associates } \\
\text { *Revenue }\end{array}$ \\
\hline 14- Ayes & $\begin{array}{l}\text { *Accounting for } \\
\text { inventories } \\
\text { *Trade Receivables } \\
\text { *Impairment }\end{array}$ & $\begin{array}{l}\text { *accounting for } \\
\text { inventories } \\
\text { *Trade Receivables } \\
\text { *Impairment }\end{array}$ & *financial liabilities \\
\hline 15- Aygaz & *Financial investments & *Financial investments & *Financial investments \\
\hline 16- Bagfaş & $\begin{array}{l}* \text { Recognition of } \\
\text { Revenue }\end{array}$ & $\begin{array}{l}\text { *Recognition of } \\
\text { Revenue }\end{array}$ & $\begin{array}{l}* \text { Recognition of } \\
\text { Revenue }\end{array}$ \\
\hline $\begin{array}{l}\text { 17- Bak } \\
\text { Ambalaj }\end{array}$ & $\begin{array}{l}\text { *Investments in } \\
\text { Progress } \\
\text { *Capitalization of } \\
\text { borrowing costs }\end{array}$ & $*$ Tangible fixed assets & *Tangible fixed assets \\
\hline 18-Bantaş & $\begin{array}{l}\text { *Tangible fixed assets } \\
\text { *Trade Payables } \\
\text { Financial liability } \\
\text { *Trade Receivables }\end{array}$ & $\begin{array}{l}\text { *Tangible fixed assets } \\
\text { *Trade Payables } \\
\text { Financial liability } \\
\text { *Trade Receivables }\end{array}$ & $\begin{array}{l}\text { *Tangible fixed assets } \\
\text { *Trade Payables } \\
\text { Financial liability } \\
\text { *Trade Receivables } \\
\text { *Inventories }\end{array}$ \\
\hline $\begin{array}{l}\text { 19- Baştaş } \\
\text { Çimento }\end{array}$ & $\begin{array}{l}\text { *Deferred tax assets } \\
\text { *Goodwill } \\
\text { *Stock purchase }\end{array}$ & *Goodwill & *Tangible fixed assets \\
\hline 20- Batıçim & $\begin{array}{l}* \text { Capitalization of } \\
\text { borrowing costs } \\
* \text { Tangible fixed assets }\end{array}$ & $\begin{array}{l}* \text { Capitalization of } \\
\text { borrowing costs } \\
* \text { Tangible fixed assets }\end{array}$ & $\begin{array}{l}\text { *Inventory Value } \\
\text { Impairment } \\
\text { *Deferred tax assets }\end{array}$ \\
\hline 21- Batısöke & $\begin{array}{l}\text { *Capitalization of } \\
\text { borrowing costs } \\
* \text { Tangible fixed assets }\end{array}$ & $\begin{array}{l}* \text { Capitalization of } \\
\text { borrowing costs } \\
* \text { Tangible fixed assets }\end{array}$ & $\begin{array}{l}\text { *Inventory Value } \\
\text { Impairment } \\
\text { *Deferred tax assets }\end{array}$ \\
\hline 22-Berkosan & *Trade Receivables & *Trade Receivables & *Revenue \\
\hline 23-Bilici & *Revenue & $\begin{array}{l}\text { *Revenue } \\
* \text { Tangible fixed assets }\end{array}$ & *Revenue \\
\hline $\begin{array}{l}\text { 24-Bolu } \\
\text { Çimento }\end{array}$ & $\begin{array}{l}\text { *Impairment of shares } \\
\text { in associates } \\
\text { *Revenue }\end{array}$ & $\begin{array}{l}\text { *Impairment of shares } \\
\text { in associates } \\
* \text { Revenue }\end{array}$ & $\begin{array}{l}\text { *Impairment of shares } \\
\text { in associates } \\
\text { *Revenue }\end{array}$ \\
\hline 25-Burçelik & Deferred tax assets & $\begin{array}{l}\text { Deferred tax assets } \\
\text { *Revenue }\end{array}$ & *Revenue \\
\hline 26- Borusan & $\begin{array}{l}\text { *Evaluation of } \\
\text { Impairment } \\
* \text { Tangible fixed assets }\end{array}$ & $\begin{array}{l}\text { *Revenue } \\
* \text { Tangible fixed assets }\end{array}$ & $\begin{array}{l}\text { *Revenue } \\
\text { *Tangible fixed assets }\end{array}$ \\
\hline $\begin{array}{l}\text { 27- Bosch } \\
\text { Fren }\end{array}$ & *Revenue & *Revenue & *Revenue \\
\hline $\begin{array}{l}\text { 28- Bossa } \\
\text { Ticaret }\end{array}$ & $\begin{array}{l}\text { *Tangible fixed assets } \\
\text { *Accounting of merger } \\
\text { transactions }\end{array}$ & $\begin{array}{l}\text { *Tangible fixed assets } \\
\text { *Investment incentives } \\
\text { *Capitalization of } \\
\text { borrowing costs }\end{array}$ & $\begin{array}{l}\text { *Trade Receivables- } \\
\text { Impairment }\end{array}$ \\
\hline
\end{tabular}


KAUJEASF 12(24), 2021: 753-780

\begin{tabular}{|c|c|c|c|}
\hline 29- Brise & $\begin{array}{l}\text { *Revenue } \\
\text { *Trade Receivables }\end{array}$ & $\begin{array}{l}\text { *Revenue } \\
\text { *Trade Receivables }\end{array}$ & $\begin{array}{l}\text { *Revenue } \\
\text { *Trade Receivables }\end{array}$ \\
\hline $\begin{array}{l}\text { 30- Coca- } \\
\text { Cola }\end{array}$ & *Intangible fixed assets & $\begin{array}{l}\text { *Goodwill } \\
\text { *Intangible fixed } \\
\text { assets }\end{array}$ & $\begin{array}{l}\text { *Goodwill } \\
\text { *Intangible fixed } \\
\text { assets }\end{array}$ \\
\hline $\begin{array}{l}\text { 31- Çelik } \\
\text { Halat }\end{array}$ & *Revenue & *Revenue & *Revenue \\
\hline $\begin{array}{l}\text { 32- Çemaş } \\
\text { Döküm }\end{array}$ & $\begin{array}{l}\text { *Related party } \\
\text { transactions } \\
\text { *Trade Receivables } \\
\text { *Trade payables }\end{array}$ & $\begin{array}{l}\text { *Related party } \\
\text { transactions } \\
\text { *Trade Receivables } \\
\text { *Trade payables }\end{array}$ & $\begin{array}{l}\text { *Related party } \\
\text { transactions } \\
\text { *Trade Receivables } \\
\text { *Trade payables }\end{array}$ \\
\hline 33-Çimsa & $\begin{array}{l}\text { *Goodwill } \\
\text { *Financial costs }\end{array}$ & $\begin{array}{l}\text { *Goodwill } \\
\text { *Financial costs }\end{array}$ & *Goodwill \\
\hline $\begin{array}{l}\text { 34- } \\
\text { Çuhadaroğlu }\end{array}$ & $\begin{array}{l}\text { *Revenue } \\
\text { *Tangible fixed assets }\end{array}$ & *Revenue & $\begin{array}{l}\text { *Trade Receivables } \\
\text { *Inventories }\end{array}$ \\
\hline 35-Dardenel & $\begin{array}{l}\text { *Revenue } \\
\text { *Trade Receivables }\end{array}$ & $\begin{array}{l}\text { *Revenue } \\
\text { *Trade Receivables }\end{array}$ & $\begin{array}{l}\text { *Revenue } \\
\text { *Trade Receivables }\end{array}$ \\
\hline 36-Demirsaş & $\begin{array}{l}\text { *Trade Receivables } \\
\text { *Revenue } \\
\text { *Inventories }\end{array}$ & $\begin{array}{l}\text { *Trade Receivables } \\
\text { *Revenue } \\
\text { *Inventories }\end{array}$ & $\begin{array}{l}\text { *Revenue } \\
\text { *Trade Receivables } \\
\text { *Inventories }\end{array}$ \\
\hline $\begin{array}{l}\text { 37-Denizli } \\
\text { Cam }\end{array}$ & $\begin{array}{l}\text { *Auditing the Auditor's } \\
\text { History and Opening } \\
\text { Balances } \\
\text { *Deferred tax assets } \\
\text { *Provisions for } \\
\text { Employee Benefits }\end{array}$ & $\begin{array}{l}\text { *Revenue } \\
* \text { Tangible fixed assets } \\
* \text { Deferred tax assets }\end{array}$ & $\begin{array}{l}\text { *Revenue } \\
\text { *Inventories }\end{array}$ \\
\hline $\begin{array}{l}\text { 38-Desa } \\
\text { Deri }\end{array}$ & $\begin{array}{l}* \text { Provisions for tax } \\
\text { penalties } \\
* \text { Tangible fixed assets }\end{array}$ & $\begin{array}{l}\text { *Revenue } \\
* \text { Provisions for tax } \\
\text { penalties } \\
* \text { Tangible fixed assets } \\
* \text { Inventories } \\
\end{array}$ & $\begin{array}{l}\text { *Revenue } \\
\text { *Tangible fixed assets } \\
\text { *Inventories }\end{array}$ \\
\hline $\begin{array}{l}\text { 39-Deva } \\
\text { Holding }\end{array}$ & $\begin{array}{l}\text { *Capitalized } \\
\text { development costs } \\
\text { *Inventories }\end{array}$ & $\begin{array}{l}\text { *Capitalized } \\
\text { development costs } \\
\text { *Inventories }\end{array}$ & $\begin{array}{l}\text { *Capitalized } \\
\text { development costs } \\
\text { *Inventories }\end{array}$ \\
\hline 40-Diriteks & $\begin{array}{l}\text { *Inventories } \\
* \text { Revaluation } \\
\end{array}$ & *Inventories & $\begin{array}{l}\text { *Management reviews } \\
\text { *Financial liabilities }\end{array}$ \\
\hline 41-Ditaş & *Revenue & *Revenue & $*$ Revenue \\
\hline $\begin{array}{l}\text { 42-Doğan } \\
\text { Burda }\end{array}$ & *Recording of income & $*$ Recording of income & *Recording of income \\
\hline $\begin{array}{l}\text { 43-Doğtaş } \\
\text { Kelebek }\end{array}$ & $\begin{array}{l}\text { *Trade Receivables } \\
\text { *Inventory Velue } \\
\text { Impairment } \\
\end{array}$ & $\begin{array}{l}\text { *Revenue } \\
\text { *Management reviews }\end{array}$ & $\begin{array}{l}\text { *Revenue } \\
\text { *financial liabilities }\end{array}$ \\
\hline $\begin{array}{l}\text { 44-Duran } \\
\text { Doğan }\end{array}$ & $\begin{array}{l}\text { *Revenue } \\
\text { *Internal control }\end{array}$ & $*$ Revenue & *Revenue \\
\hline $\begin{array}{l}\text { 45-DYO } \\
\text { Boya }\end{array}$ & $\begin{array}{l}\text { *Land and buildings } \\
\text { *Trade Receivables }\end{array}$ & $\begin{array}{l}\text { *Land and buildings } \\
\text { *Trade Receivables }\end{array}$ & $\begin{array}{l}\text { *Land and buildings } \\
\text { *Trade Receivables }\end{array}$ \\
\hline
\end{tabular}


KAUJEASF 12(24), 2021: 753-780

\begin{tabular}{|c|c|c|c|}
\hline $\begin{array}{l}\text { 46-Ege } \\
\text { Endüstri }\end{array}$ & $\begin{array}{l}\text { *Investments in } \\
\text { Progress }\end{array}$ & $\begin{array}{l}\text { *Business } \\
\text { combinations and } \\
\text { goodwill }\end{array}$ & *Business combination \\
\hline $\begin{array}{l}\text { 47-Ege } \\
\text { Gübre }\end{array}$ & $\begin{array}{l}\text { *Inventories } \\
* \text { Tangible fixed assets }\end{array}$ & $\begin{array}{l}\text { *Inventories } \\
* \text { Tangible fixed assets }\end{array}$ & $\begin{array}{l}\text { *Inventories } \\
* \text { Tangible fixed assets }\end{array}$ \\
\hline $\begin{array}{l}\text { 48-Ege } \\
\text { Profil }\end{array}$ & $\begin{array}{l}\text { *Trade Receivables } \\
\text { Deferred tax assets }\end{array}$ & *Trade Receivables & *Trade Receivables \\
\hline $\begin{array}{l}\text { 49-Ege } \\
\text { Seramik }\end{array}$ & *Revenue & *Revenue & $\begin{array}{l}\text { *Revenue } \\
\text { *Consolidated } \\
\text { financial statements } \\
\end{array}$ \\
\hline 50-Erbosan & $\begin{array}{l}\text { *Foreign currency } \\
\text { transactions }\end{array}$ & $\begin{array}{l}* \text { Foreign currency } \\
\text { transactions }\end{array}$ & $\begin{array}{l}\text { *Foreign currency } \\
\text { transactions }\end{array}$ \\
\hline $\begin{array}{l}\text { 51-Ereğli } \\
\text { Demir ve } \\
\text { Çelik }\end{array}$ & $\begin{array}{l}\text { *Revenue } \\
\text { *Depreciation }\end{array}$ & *Revenue & $\begin{array}{l}\text { *Revenue } \\
\text { *Consolidated } \\
\text { financial statements }\end{array}$ \\
\hline 52-Ford & $\begin{array}{l}\text { *Cash Flow Hedge } \\
\text { Accounting } \\
\text { *Warranty Provision }\end{array}$ & $\begin{array}{l}\text { *Cash Flow Hedge } \\
\text { Accounting } \\
\text { *Warranty Provision }\end{array}$ & $\begin{array}{l}\text { *Cash Flow Hedge } \\
\text { Accounting } \\
\text { *Warranty Provision } \\
\text { *The Leases Standard }\end{array}$ \\
\hline 53-Gediz & $\begin{array}{l}\text { *Trade Receivables } \\
\text { *Revenue } \\
\text { *Tangible fixed assets }\end{array}$ & $\begin{array}{l}\text { *Trade Receivables } \\
\text { *Revenue }\end{array}$ & $\begin{array}{l}\text { *Trade Receivables } \\
\text { *Revenue }\end{array}$ \\
\hline 54-Gentaş & $\begin{array}{l}\text { *Transactions and } \\
\text { balances with related } \\
\text { parties }\end{array}$ & $\begin{array}{l}* \text { Transactions and } \\
\text { balances with related } \\
\text { parties } \\
\text { *Revenue } \\
\end{array}$ & $\begin{array}{l}\text { *Transactions and } \\
\text { balances with related } \\
\text { parties } \\
\text { *Revenue } \\
\end{array}$ \\
\hline 55-Göltaş & Deferred tax assets & $\begin{array}{l}\text { Deferred tax assets } \\
\text { *Revenue }\end{array}$ & $\begin{array}{l}\text { *Revenue } \\
\text { *Litigations }\end{array}$ \\
\hline 56-Gersan & $\begin{array}{l}\text { *Inventories } \\
\text { *Tangible fixed assets } \\
\text { *Trade Receivables }\end{array}$ & $\begin{array}{l}\text { *Inventories } \\
\text { *Tangible fixed assets } \\
\text { *Trade Receivables }\end{array}$ & $\begin{array}{l}\text { *Trade Receivables } \\
\text { *Inventories }\end{array}$ \\
\hline 57-Gübretaş & *Trade Receivables & Deferred tax assets & Deferred tax assets \\
\hline 58-Hateks & $\begin{array}{l}\text { *Tangible fixed assets } \\
\text { *Trade Receivables }\end{array}$ & *Trade Receivables & *Tangible fixed assets \\
\hline 59-Hektaş & $\begin{array}{l}\text { *Trade Receivables } \\
\text { *Business combinations } \\
\text { *Goodwill }\end{array}$ & $\begin{array}{l}\text { *Revenue } \\
\text { *Trade Receivables } \\
\text { *Goodwill }\end{array}$ & $\begin{array}{l}\text { *Revenue } \\
\text { *Trade Receivables } \\
\text { *Business } \\
\text { combinations }\end{array}$ \\
\hline $\begin{array}{l}\text { 60- Hürriyet } \\
\text { Gazetecilik }\end{array}$ & $\begin{array}{l}\text { *Intangible fixed assets } \\
\text { *Revaluation of real } \\
\text { estate } \\
\text { *Land and buildings }\end{array}$ & $\begin{array}{l}\text { *Revaluation of real } \\
\text { estate } \\
\text { *Land and buildings }\end{array}$ & $\begin{array}{l}\text { *Revaluation of real } \\
\text { estate } \\
\text { *Land and buildings }\end{array}$ \\
\hline $\begin{array}{l}\text { 61- İhlas Ev } \\
\text { Aletleri }\end{array}$ & $\begin{array}{l}\text { *Trade Receivables } \\
\text { *Inventory Velue } \\
\text { Impairment } \\
\text { *Appreciation of real } \\
\text { estate }\end{array}$ & $\begin{array}{l}\text { *Trade Receivables } \\
\text { *Inventory Velue } \\
\text { Impairment } \\
\text { *Appreciation of real } \\
\text { estate }\end{array}$ & $\begin{array}{l}\text { *Trade Receivables } \\
\text { *Inventory Value } \\
\text { Impairment } \\
\text { *Appreciation of real } \\
\text { estate }\end{array}$ \\
\hline
\end{tabular}


KAUJEASF 12(24), 2021: 753-780

\begin{tabular}{|c|c|c|c|}
\hline & $\begin{array}{l}\text { *Intangible fixed assets } \\
\text { *Revenue }\end{array}$ & $\begin{array}{l}\text { *Intangible fixed } \\
\text { assets } \\
\text { *Revenue }\end{array}$ & $\begin{array}{l}* \text { Intangible fixed } \\
\text { assets } \\
* \text { Revenue }\end{array}$ \\
\hline $\begin{array}{l}\text { 62- İhlas } \\
\text { Gazetecilik }\end{array}$ & $\begin{array}{l}\text { *Trade Receivables } \\
\text { *Recoverability of the } \\
\text { investment valued by } \\
\text { equity method } \\
\text { *Appreciation of real } \\
\text { estate } \\
\text { *Intangible fixed assets } \\
\text { *Provision for } \\
\text { severance pay } \\
\text { *Revenue }\end{array}$ & $\begin{array}{l}\text { *Trade Receivables } \\
\text { *Recoverability of the } \\
\text { investment valued by } \\
\text { equity method } \\
\text { *Appreciation of real } \\
\text { estate } \\
\text { *Intangible fixed } \\
\text { assets } \\
\text { *Provision for } \\
\text { severance pay } \\
\text { *Revenue }\end{array}$ & $\begin{array}{l}\text { *Trade Receivables } \\
\text { *Recoverability of the } \\
\text { investment valued by } \\
\text { equity method } \\
\text { *Appreciation of real } \\
\text { estate } \\
\text { *Intangible fixed } \\
\text { assets } \\
\text { *Provision for } \\
\text { severance pay } \\
\text { *Revenue }\end{array}$ \\
\hline $\begin{array}{l}63- \\
\text { İskenderun } \\
\text { Demir }\end{array}$ & $\begin{array}{l}\text { *Revenue } \\
\text { *Depreciation }\end{array}$ & $\begin{array}{l}\text { *Revenue } \\
\text { *Depreciation }\end{array}$ & $\begin{array}{l}\text { *Revenue } \\
\text { *The Leases Standard }\end{array}$ \\
\hline $\begin{array}{l}\text { 64- İzmir } \\
\text { Demir Çelik }\end{array}$ & $\begin{array}{l}\text { *Revenue } \\
\text { *Trade Receivables }\end{array}$ & $\begin{array}{l}\text { *Revenue } \\
\text { *Trade Receivables }\end{array}$ & $\begin{array}{l}\text { *Revenue } \\
\text { *Trade Receivables } \\
\text { *Tangible fixed assets }\end{array}$ \\
\hline 65- Jantsa & $\begin{array}{l}\text { *Tangible fixed assets } \\
\text { *Provisions for } \\
\text { Employee Benefits } \\
\text { *Trade Receivables }\end{array}$ & $\begin{array}{l}\text { *Tangible fixed assets } \\
* \text { Provisions for } \\
\text { Employee Benefits } \\
\text { *Inventory Value } \\
\text { Impairment }\end{array}$ & $\begin{array}{l}\text { *Tangible fixed assets } \\
\text { *Revenue }\end{array}$ \\
\hline $\begin{array}{l}66- \\
\text { Kaplamin }\end{array}$ & $\begin{array}{l}\text { *Revenue } \\
\text { *Trade Receivables }\end{array}$ & $\begin{array}{l}\text { *Revenue } \\
* \text { Trade Receivables }\end{array}$ & $\begin{array}{l}\text { *Revenue } \\
\text { *Trade Receivables }\end{array}$ \\
\hline 67-Klimasan & $\begin{array}{l}* \text { Bill and keep } \\
\text { transactions }\end{array}$ & $\begin{array}{l}\text { *Bill and keep } \\
\text { transactions } \\
\text { *Revenue }\end{array}$ & $\begin{array}{l}\text { *Revenue } \\
\text { *Trade Receivables }\end{array}$ \\
\hline 68-Kardemir & $\begin{array}{l}\text { *Goodwill } \\
\text { *Inventory Value } \\
\text { Impairment } \\
\text { *Investment incentives } \\
\text { *Depreciation } \\
\text { *Compliance with } \\
\text { financial ratios }\end{array}$ & $\begin{array}{l}\text { *Inventory Value } \\
\text { Impairment } \\
\text { *Depreciation } \\
\text { *Tangible fixed assets }\end{array}$ & *Revenue \\
\hline 69-Karsan & $\begin{array}{l}\text { *Provision for warranty } \\
\text { *Capitalized } \\
\text { development costs }\end{array}$ & $\begin{array}{l}\text { *Provision for } \\
\text { warranty } \\
\text { *Capitalized } \\
\text { development costs }\end{array}$ & $\begin{array}{l}\text { *Provision for } \\
\text { warranty } \\
\text { *Capitalized } \\
\text { development costs }\end{array}$ \\
\hline 70-Karsu & $\begin{array}{l}\text { *Trade Receivables } \\
\text { *Inventories } \\
\text { *Revenue }\end{array}$ & $\begin{array}{l}\text { *Trade Receivables } \\
\text { *Inventories } \\
\text { *Revenue }\end{array}$ & $\begin{array}{l}\text { *Trade Receivables } \\
\text { *Inventories } \\
\text { *Revenue }\end{array}$ \\
\hline $\begin{array}{l}71- \\
\text { Kartonsan }\end{array}$ & $\begin{array}{l}\text { *Trade Receivables } \\
\text { *Inventories } \\
\text { *Tangible fixed assets } \\
\text { *Revenue }\end{array}$ & $\begin{array}{l}\text { *Trade Receivables } \\
\text { *Inventories } \\
\text { *Tangible fixed assets } \\
\text { *Revenue }\end{array}$ & $\begin{array}{l}\text { *Trade Receivables } \\
\text { *Inventories } \\
\text { *Tangible fixed assets } \\
\text { *Revenue } \\
\end{array}$ \\
\hline
\end{tabular}


KAUJEASF 12(24), 2021: 753-780

\begin{tabular}{|c|c|c|c|}
\hline 72-Konfrut & $\begin{array}{l}\text { *Inventories } \\
\text { *Revenue }\end{array}$ & $\begin{array}{l}\text { *Inventories } \\
\text { *Revenue }\end{array}$ & $\begin{array}{l}\text { *Inventories } \\
\text { *Trade Receivables }\end{array}$ \\
\hline $\begin{array}{l}\text { 73-Konya } \\
\text { Çimento }\end{array}$ & $\begin{array}{l}\text { *Trade Receivables } \\
\text { *Provisions for } \\
\text { severance pay }\end{array}$ & $\begin{array}{l}\text { *Provisions for } \\
\text { severance pay }\end{array}$ & *Tangible fixed assets \\
\hline 74-Kordsa & *Revenue & $\begin{array}{l}\text { *Revenue } \\
\text { *Business } \\
\text { combinations }\end{array}$ & $\begin{array}{l}\text { *Revenue } \\
\text { *Business } \\
\text { combinations }\end{array}$ \\
\hline $\begin{array}{l}\text { 75-Makine } \\
\text { Takım } \\
\text { Endüstri }\end{array}$ & $\begin{array}{l}\text { *Trade Receivables } \\
\text { *Revenue }\end{array}$ & $\begin{array}{l}\text { *Trade Receivables } \\
\text { *Revenue }\end{array}$ & *Revenue \\
\hline $\begin{array}{l}\text { 76-Mardin } \\
\text { Çimento }\end{array}$ & *Revenue & *Revenue & *Revenue \\
\hline $\begin{array}{l}\text { 77-Marshall } \\
\text { Boya }\end{array}$ & *Trade Receivables & *Trade Receivables & *Trade Receivables \\
\hline $\begin{array}{l}\text { 78-Menders } \\
\text { Tekstil }\end{array}$ & $\begin{array}{l}\text { *Revenue } \\
\text { *Provisions for } \\
\text { severance pay } \\
\text { *Tangible fixed assets }\end{array}$ & $\begin{array}{l}\text { *Revenue } \\
\text { *Trade Receivables } \\
\text { *Provisions for } \\
\text { severance pay } \\
\text { *inventory valuation }\end{array}$ & $\begin{array}{l}\text { *Revenue } \\
\text { *Trade Receivables } \\
\text { *inventory valuation }\end{array}$ \\
\hline 79-Niğbaş & *Revenue & *Revenue & *Revenue \\
\hline $\begin{array}{l}\text { 80-Nuh } \\
\text { Çimento }\end{array}$ & $\begin{array}{l}\text { *Revenue } \\
\text { *Impairment tests }\end{array}$ & $\begin{array}{l}\text { *Revenue } \\
\text { *Impairment tests }\end{array}$ & $\begin{array}{l}\text { *Revenue } \\
\text { *Impairment tests }\end{array}$ \\
\hline $\begin{array}{l}81- \\
\text { Olmuksan }\end{array}$ & $\begin{array}{l}\text { *Doubtful trade } \\
\text { receivables } \\
\text { *Impairment of assets }\end{array}$ & $\begin{array}{l}\text { *Doubtful trade } \\
\text { receivables } \\
\text { *Impairment of assets }\end{array}$ & $\begin{array}{l}* \text { Expected loss } \\
\text { provision }\end{array}$ \\
\hline $\begin{array}{l}\text { 82-Orma } \\
\text { Orman } \\
\text { Mahsulleri }\end{array}$ & $\begin{array}{l}\text { Deferred tax assets } \\
* \text { Tangible fixed assets }\end{array}$ & $\begin{array}{l}\text { Deferred tax assets } \\
* \text { Tangible fixed assets }\end{array}$ & $\begin{array}{l}\text { *Revenue } \\
* \text { Tangible fixed assets }\end{array}$ \\
\hline $\begin{array}{l}\text { 83-Otokar } \\
\text { Otomotiv }\end{array}$ & $\begin{array}{l}\text { *Provision for Warranty } \\
\text { Expenses }\end{array}$ & $\begin{array}{l}\text { *Provision for } \\
\text { Warranty Expenses }\end{array}$ & $\begin{array}{l}\text { *Provision for } \\
\text { Warranty Expenses }\end{array}$ \\
\hline $\begin{array}{l}\text { 84-Özbal } \\
\text { Çelik }\end{array}$ & $\begin{array}{l}\text { *Inventory Value } \\
\text { Impairment } \\
\text { *Trade Receivables }\end{array}$ & $\begin{array}{l}\text { *Inventory Value } \\
\text { Impairment } \\
\text { *Trade Receivables }\end{array}$ & $\begin{array}{l}\text { *Inventory Value } \\
\text { Impairment } \\
\text { *Trade Receivables }\end{array}$ \\
\hline $\begin{array}{l}\text { 85-Özerden } \\
\text { Plastik }\end{array}$ & *Real estate valuation & *Real estate valuation & *Real estate valuation \\
\hline 86-Parsan & $\begin{array}{l}\text { *Revenue } \\
* \text { Tangible fixed assets }\end{array}$ & $\begin{array}{l}\text { *Revenue } \\
* \text { Tangible fixed assets }\end{array}$ & $\begin{array}{l}\text { *Revenue } \\
* \text { Tangible fixed assets }\end{array}$ \\
\hline $\begin{array}{l}\text { 87-Penguen } \\
\text { Gida }\end{array}$ & *Real estate valuation & Deferred tax assets & $\begin{array}{l}\text { *Tangible fixed assets } \\
\text { * Real estate valuation } \\
\text { Deferred tax assets }\end{array}$ \\
\hline 88-Petkim & *Ongoing tax reviews & *Ongoing tax cases & *Ongoing tax cases \\
\hline 89-Pınar Et & *Land and buildings & *Land and buildings & *Land and buildings \\
\hline 90-Pınar Su & $\begin{array}{l}\text { *Land and buildings } \\
* \text { Accounting policy } \\
\text { change } \\
* \text { Trade Receivables }\end{array}$ & $\begin{array}{l}\text { *Land and buildings } \\
\text { *Trade Receivables }\end{array}$ & $\begin{array}{l}\text { *Land and buildings } \\
\text { *Trade Receivables }\end{array}$ \\
\hline
\end{tabular}


KAUJEASF 12(24), 2021: 753-780

\begin{tabular}{|c|c|c|c|}
\hline 91-Pınar Süt & *Land and buildings & *Land and buildings & *Land and buildings \\
\hline $\begin{array}{l}92- \\
\text { Politeknik }\end{array}$ & $\begin{array}{l}\text { *Trade Receivables } \\
\text { *Inventory Value } \\
\text { Impairment }\end{array}$ & $\begin{array}{l}\text { *Trade Receivables } \\
\text { *Inventory Value } \\
\text { Impairment }\end{array}$ & $\begin{array}{l}\text { *Trade Receivables } \\
\text { *Inventory Value } \\
\text { Impairment }\end{array}$ \\
\hline $\begin{array}{l}\text { 93-Rodrigo } \\
\text { Tekstil }\end{array}$ & $\begin{array}{l}\text { *Revenue } \\
\text { *Doubtful trade } \\
\text { receivables }\end{array}$ & $\begin{array}{l}\text { *Revenue } \\
\text { *Doubtful trade } \\
\text { receivables }\end{array}$ & $\begin{array}{l}\text { *Inventories } \\
\text { *Revenue }\end{array}$ \\
\hline $\begin{array}{l}\text { 94-RTA } \\
\text { Laboratuvarı } \\
\text { Biyolojik } \\
\text { Ürünleri }\end{array}$ & $\begin{array}{l}* \text { Tangible fixed assets } \\
* \text { Trade Receivables }\end{array}$ & $\begin{array}{l}\text { *Tangible fixed assets } \\
* \text { Trade Receivables }\end{array}$ & $\begin{array}{l}\text { *Trade Receivables } \\
\text { *Inventories }\end{array}$ \\
\hline 95-Safkar & $\begin{array}{l}\text { *Trade Receivables } \\
* \text { Goodwill }\end{array}$ & $\begin{array}{l}\text { *Trade Receivables } \\
\text { *Revenue }\end{array}$ & $\begin{array}{l}\text { *Trade Receivables } \\
\text { *Revenue }\end{array}$ \\
\hline $\begin{array}{l}\text { 96-Sanifoam } \\
\text { Sünger } \\
\text { Sanayi }\end{array}$ & $\begin{array}{l}\text { *Impairment in } \\
\text { inventories } \\
\text { *Tangible fixed assets } \\
\text { *Revenue }\end{array}$ & $\begin{array}{l}\text { *Trade Receivables } \\
\text { *Impairment in } \\
\text { inventories } \\
\text { *Tangible fixed assets } \\
\text { *Revenue }\end{array}$ & $\begin{array}{l}\text { *Trade Receivables } \\
\text { *Real estate valuation }\end{array}$ \\
\hline $\begin{array}{l}\text { 97-Saray } \\
\text { Matbaacilık }\end{array}$ & $\begin{array}{l}\text { *Revenue } \\
\text { *Inventories } \\
\text { *Financial liabilities } \\
\text { *Corporate Tax } \\
\text { Exemption Application }\end{array}$ & $\begin{array}{l}\text { *Revenue } \\
\text { *Inventories } \\
\text { *Financial liabilities }\end{array}$ & $\begin{array}{l}\text { *Revenue } \\
\text { *Inventories } \\
\text { *Financial liabilities }\end{array}$ \\
\hline $\begin{array}{l}\text { 98- } \\
\text { Sarkuysan }\end{array}$ & $\begin{array}{l}\text { *Trade Receivables } \\
\text { *Real estate valuation } \\
\text { *Financial liabilities } \\
\text { *Revenue }\end{array}$ & $\begin{array}{l}\text { *Trade Receivables } \\
\text { *Real estate valuation } \\
\text { *Financial liabilities } \\
\text { *Revenue }\end{array}$ & $\begin{array}{l}\text { *Trade Receivables } \\
\text { *Real estate valuation } \\
\text { *Financial liabilities } \\
\text { *Revenue }\end{array}$ \\
\hline $\begin{array}{l}\text { 99-Sasa } \\
\text { Polyester }\end{array}$ & $\begin{array}{l}\text { *Tangible fixed assets } \\
* \text { Revenue }\end{array}$ & $\begin{array}{l}\text { *Revenue } \\
\text { *Investment incentive } \\
\text { *Borrowing cost }\end{array}$ & $\begin{array}{l}\text { *Revenue } \\
\text { Deferred tax assets } \\
\text { *Borrowing cost }\end{array}$ \\
\hline $\begin{array}{l}\text { 100-Say } \\
\text { Reklamcilık }\end{array}$ & $\begin{array}{l}\text { *Revenue } \\
\text { *Trade Receivables } \\
\text { *Assets subject to } \\
\text { operating lease }\end{array}$ & $\begin{array}{l}\text { *Revenue } \\
\text { *Impairment in } \\
\text { inventories }\end{array}$ & $\begin{array}{l}\text { *Revenue } \\
\text { *Inventory Value } \\
\text { Impairment }\end{array}$ \\
\hline $\begin{array}{l}\text { 101-Sekuro } \\
\text { Plastik } \\
\text { Ambalaj }\end{array}$ & $\begin{array}{l}\text { *Tangible fixed assets } \\
\text { *Elimination processes } \\
\text { *Financial liabilities } \\
\text { *Trade Receivables }\end{array}$ & $\begin{array}{l}\text { *Elimination processes } \\
\text { *Financial liabilities } \\
\text { *Trade Receivables } \\
\text { *Borrowing cost }\end{array}$ & $\begin{array}{l}\text { *Trade Receivables } \\
\text { *Trade payables } \\
\text { *Revenue }\end{array}$ \\
\hline $\begin{array}{l}102- \\
\text { Silverline } \\
\text { Endüstri } \\
\end{array}$ & $\begin{array}{l}\text { *Subsidiary legal } \\
\text { mergers }\end{array}$ & $\begin{array}{l}* \text { Transactions with the } \\
\text { related party }\end{array}$ & $\begin{array}{l}\text { *Transactions with the } \\
\text { related party }\end{array}$ \\
\hline $\begin{array}{l}\text { 103-Soda } \\
\text { Sanayi }\end{array}$ & *Inventories & $\begin{array}{l}\text { *Revenue } \\
\text { *Tangible fixed assets } \\
\text { Deferred tax assets }\end{array}$ & *Hedging \\
\hline 104-Sodaş & $\begin{array}{l}\text { *Inventory valuation } \\
\text { method }\end{array}$ & $\begin{array}{l}\text { *Inventory valuation } \\
\text { method }\end{array}$ & $\begin{array}{l}\text { *Inventory valuation } \\
\text { method }\end{array}$ \\
\hline
\end{tabular}


KAUJEASF 12(24), 2021: 753-780

\begin{tabular}{|c|c|c|c|}
\hline 105-Söktaş & $\begin{array}{l}\text { *Tangible fixed assets } \\
\text { *Financial liabilities }\end{array}$ & $\begin{array}{l}* \text { Tangible fixed assets } \\
* \text { Financial liabilities }\end{array}$ & $\begin{array}{l}\text { *Tangible fixed assets } \\
\text { *Financial liabilities }\end{array}$ \\
\hline $\begin{array}{l}\text { 106-Sönmez } \\
\text { Holding }\end{array}$ & $\begin{array}{l}\text { *Financial investments } \\
\text { *Revenue }\end{array}$ & $\begin{array}{l}\text { *Investments valued } \\
\text { by equity method } \\
\text { *Revenue }\end{array}$ & *Revenue \\
\hline 107-Sumaş & $\begin{array}{l}\text { *Revenue } \\
\text { *Provisions for } \\
\text { severance pay } \\
\text { *Inventories }\end{array}$ & $\begin{array}{l}\text { *Revenue } \\
\text { *Provisions for } \\
\text { severance pay } \\
\text { *Inventories }\end{array}$ & $\begin{array}{l}\text { *Revenue } \\
\text { *Provisions for } \\
\text { severance pay } \\
\text { *Inventories }\end{array}$ \\
\hline $\begin{array}{l}\text { 108-Tat } \\
\text { G1da }\end{array}$ & $\begin{array}{l}\text { *Revenue } \\
\text { *Inventory Value } \\
\text { Impairment } \\
\end{array}$ & $\begin{array}{l}\text { *Revenue } \\
\text { *Inventory Value } \\
\text { Impairment }\end{array}$ & $\begin{array}{l}\text { *Revenue } \\
\text { *Inventory Value } \\
\text { Impairment } \\
\end{array}$ \\
\hline $\begin{array}{l}109-\text { Taze } \\
\text { Kuru Sanayi }\end{array}$ & *Inventories & *Inventories & $\begin{array}{l}\text { *Tangible fixed assets } \\
* \text { Trade Receivables }\end{array}$ \\
\hline $\begin{array}{l}\text { 110- } \\
\text { Temapol }\end{array}$ & $\begin{array}{l}\text { *Tangible fixed assets } \\
\text { *Trade Receivables } \\
\text { * Revenue } \\
\text { *Financial liabilities } \\
\text { *Inventories }\end{array}$ & *Tangible fixed assets & $\begin{array}{l}\text { *Revenue } \\
\text { *Tangible fixed assets }\end{array}$ \\
\hline 111-Tofaş & $\begin{array}{l}\text { *Capitalized } \\
\text { development costs } \\
\text { *Provision for warranty } \\
\text { *Receivables from } \\
\text { finance sector activities } \\
\text { *Provisions for } \\
\text { severance pay }\end{array}$ & $\begin{array}{l}\text { *Capitalized } \\
\text { development costs } \\
\text { *Provision for } \\
\text { warranty } \\
\text { * Receivables from } \\
\text { finance sector } \\
\text { activities }\end{array}$ & $\begin{array}{l}\text { *Capitalized } \\
\text { development costs } \\
\text { *Provision for } \\
\text { warranty } \\
\text { *Receivables from } \\
\text { finance sector } \\
\text { activities }\end{array}$ \\
\hline $\begin{array}{l}\text { 112-Trakya } \\
\text { Cam Sanayi }\end{array}$ & $\begin{array}{l}\text { *Auditor transition and } \\
\text { opening balances } \\
\text { *Investment incentives } \\
\text { *Provisions }\end{array}$ & $\begin{array}{l}\text { *Revenue } \\
* \text { Tangible fixed assets } \\
* \text { Investment incentives }\end{array}$ & $\begin{array}{l}\text { *Goodwill } \\
\text { *Hedge accounting }\end{array}$ \\
\hline 113-Tukaş & $\begin{array}{l}\text { *Inventory Value } \\
\text { Impairment }\end{array}$ & $\begin{array}{l}\text { *Trade Receivables } \\
\text { *Inventory Value } \\
\text { Impairment }\end{array}$ & $\begin{array}{l}* \text { Trade Receivables } \\
\text { Deferred tax assets }\end{array}$ \\
\hline $\begin{array}{l}114- \\
\text { Tümosan }\end{array}$ & $\begin{array}{l}\text { *Revenue } \\
\text { *Trade Receivables }\end{array}$ & $\begin{array}{l}\text { *Revenue } \\
\text { *Trade Receivables }\end{array}$ & *Revenue \\
\hline 115-Tüpraş & $\begin{array}{l}\text { *ash flow risk } \\
* \text { Deferred tax assets }\end{array}$ & $\begin{array}{l}\text { *Cash flow risk } \\
\text { Deferred tax assets }\end{array}$ & *Land and fields \\
\hline $\begin{array}{l}\text { 116-Türk } \\
\text { Prysmian } \\
\text { Kablo }\end{array}$ & *Trade Receivables & *Trade Receivables & *Trade Receivables \\
\hline $\begin{array}{l}\text { 117-Türk } \\
\text { Traktör }\end{array}$ & $\begin{array}{l}\text { *Warranty provisions } \\
* \text { Cash flow risk } \\
\text { Deferred tax assets }\end{array}$ & $\begin{array}{l}\text { *Warranty provisions } \\
\text { *Cash flow risk } \\
\text { Deferred tax assets }\end{array}$ & *Warranty provisions \\
\hline $\begin{array}{l}\text { 118-Türk } \\
\text { Tuborg }\end{array}$ & *Trade Receivables & *Trade Receivables & *Trade Receivables \\
\hline 119-Ulusoy & *Revenue & *Revenue & *Revenue \\
\hline
\end{tabular}


KAUJEASF 12(24), 2021: 753-780

\begin{tabular}{|c|c|c|c|}
\hline Elektrik & & & \\
\hline $\begin{array}{l}\text { 120-Uşak } \\
\text { Seramik }\end{array}$ & $\begin{array}{l}\text { *Revenue } \\
\text { *Trade Receivables }\end{array}$ & $\begin{array}{l}\text { *Revenue } \\
\text { *Trade Receivables } \\
\text { *Fixed asset valuation }\end{array}$ & $\begin{array}{l}\text { *Revenue } \\
\text { *Trade Receivables } \\
\text { Deferred tax assets }\end{array}$ \\
\hline $\begin{array}{l}\text { 121-Ülker } \\
\text { Bisküvi }\end{array}$ & $\begin{array}{l}\text { *Fair value } \\
\text { *Business combinations } \\
\text { *Buildings and lands }\end{array}$ & $\begin{array}{l}\text { *Fair value } \\
\text { *Goodwill } \\
\text { *Buildings and lands }\end{array}$ & $\begin{array}{l}\text { *Fair value } \\
\text { *Goodwill } \\
\text { *Buildings and lands }\end{array}$ \\
\hline 122-Vanet & $\begin{array}{l}\text { *Appreciation of real } \\
\text { estate } \\
\text { *Financial assets } \\
\text { *Transactions with the } \\
\text { related party }\end{array}$ & $\begin{array}{l}\text { *Appreciation of real } \\
\text { estate } \\
\text { *Transactions with the } \\
\text { related party }\end{array}$ & $\begin{array}{l}\text { *Appreciation of real } \\
\text { estate } \\
\text { *Transactions with the } \\
\text { related party }\end{array}$ \\
\hline 123-Vestel & *Cash flow & *Land and buildings & *Land and buildings \\
\hline Viking Kağıt & $\begin{array}{l}\text { *Land and buildings } \\
\text { *Trade receivables }\end{array}$ & $\begin{array}{l}\text { *Land and buildings } \\
\text { *Trade receivables }\end{array}$ & $\begin{array}{l}\text { *Land and buildings } \\
\text { *Trade receivables }\end{array}$ \\
\hline 124-Yataş & $\begin{array}{l}\text { *Revenue } \\
\text { *Inventories }\end{array}$ & $\begin{array}{l}\text { *Revenue } \\
\text { *Inventories }\end{array}$ & $\begin{array}{l}* \text { Revenue } \\
* \text { Leasings }\end{array}$ \\
\hline $\begin{array}{l}\text { 125-Yonga } \\
\text { Mobilya }\end{array}$ & *Revenue & $\begin{array}{l}\text { *Revenue } \\
* \text { Tangible fixed assets }\end{array}$ & *Revenue \\
\hline 126-Yünsa & *Revenue & *Revenue & *Revenue \\
\hline
\end{tabular}

As seen in the table above, the capital-intensive-structure of the manufacturing sector, the high level of tangible fixed assets, and the large volume of the inventories reflected on the key audit matters (Uzay ve Köylü, 2018, p. 58) Especially inventories, revenues, tangible fixed assets, and trade receivables were frequently among the KAM of businesses. Revenue item was the most emphasized issue among the KAM in the manufacturing sector, which is the subject of this study. The revenue item was followed by receivables, tangible fixed assets, and inventories. However, trade payables took a few places among the key audit matters. ISA 701 states that when determining the KAM, it is necessary to focus on fields, such as the material misstatement risk that shall be evaluated based on the auditor's judgment, and issues that managements consider in decision making.

It is observed that many companies regularly included KAM in their statements after they were suggested to add them in the independent audit statements. As also seen in the table above, the key audit reports of the companies did not change much considering based on the periods. In other words, KAM generally has consisted of similar issues, even though there have been differences sometimes. We understand that this situation arises from the fact that most companies have worked with the same audit companies over the years, and they have not changed the audit companies in these periods. 
Besides the standardization and cliche expressions determined by Kavut and Güngör (2018), in their study which they evaluate KAM in the 2017 independent audit of Borsa İstanbul companies, were also seen in this study for the years continuing.

Key audit matters are formed in the independent audit reports, by the auditor's communication about the most prominent issues, as proposed in the standards. The auditor clearly explains the key audit matters and expresses the determination process of them in the report. Thus, individuals who will benefit from these reports can acquire an easy evaluation opportunity. For example, inventories, frequently mentioned in key audit reports, are included in the key audit matter heading as the risk of impairment, provision allocations, and provision calculations. Additionally, the explanation section explains the audit procedure for inventories in detail. Again, in the revenue that is determined to be the most underlined issue, the revenue resource, and its inclusion in the financial reports are emphasized, moreover the risky situations of the revenue are underlined.

\section{RESULT}

With the publication of the independent audit standard 701, the key audit matters that are started to be included in the independent audit reports are considered as an application containing the matters regarded as significant by the auditor, as separate headings in the statements, and an application to provide the reliability and transparency especially needed by the users of these reports, based on the release rationale of the standards. In this context, key audit subjects that have been included in the independent audit reports since 2017 have been the subject of many academic studies. In this study, unlike previous studies, the change/transformation of key audit matters over the years has been examined in a three-year-period since the year of the first published report.

In the study, the key audit reports of 126 companies from the Borsa Istanbul manufacturing sector, including key audit matters in their statements in the last three years, and accessed through the official websites, were grouped by years and presented in a single table.

The necessity and importance of the independent audit process emerge with the financial crises experienced in the world and our country, bankruptcies, accounting cheats. The addition of key audit matters to audit reports, as a separate heading alongside the classical audit, resulted in a rapid and reliable introduction of the subjects to be focused on the enterprise. This result has enabled these reports to be more functional and reliable, also attract more attention. These reports include the communicating of the most significant issues by the auditor 
during the audit and then their presentation to the business top management, according to the standard.

Although there are deficiencies every year in general, it was observed that the independent audit reports regularly included KAM following the publication of the standard, outside exceptional cases. Within the context of this study, if there was any deficiency or an inaccessibility situation for even one year, the enterprise was not assessed evaluated. When the KAM communicated in the independent audit statements were examined, it was seen that the issues such as revenue recognition, inventories, trade receivables, tangible fixed assets, deferred tax assets, impairments, financial liabilities, goodwill, and provisions were the most frequently reported issues. Another interesting point in KAM was that key audit matters did not change much for the companies in different years, outside exceptional cases. The KAM of the studied enterprises were highly similar for 2017-2018 and 2019. This situation may cause the standard to divert from its purpose requiring KAM to be included in audit reports. Of course, for a company, the same subject can remain the most prominent issue for years. Revenue, inventories, and trade receivables are good examples of this situation. However, repeating the same expressions in the reports can decrease the function and significance of the KAM.

It was considered that audit of the same independent auditing companies on many of the companies for years, was effective in this consequence. If the audit firm is changed later, the KAM is also seen to differ. For instance, Acsselsan company was audited by different auditors for the final two years, and this situation emerged in key audit reports. A similar situation happened at Bossa company. Different auditors inspected this company for the latest two years, and they preferred to observe distinct key audit matters. It was observed that 19 companies among the subject companies worked with different audit firms over the years, and through this change, their KAM included in the reports differed. In this case, it is seen how decisive the auditor's judgment is in identifying KAM, and this determination reflecting on the statements.

\section{CONFLICT OF INTERESET STATEMENT}

There is no financial or non-financial conflict of interest with any institution, organization, person or between the authors related to the article.

\section{FINANCIAL SUPPORT}

The author received no financial support for this article. 
8. AUTHOR CONTRIBUTIONS

A.T: The entire article, including the literature and content analysis and the result, was carried out by the author.

9. ETHICS COMMITTEE STATEMENT AND INTELLECTUAL PROPERTY COPYRIGHTS

This manuscript has been prepared and submitted in accordance with the ethical rules. Ethics committee approval was not required for the study.

\section{REFERENCES}

Aktas, R. \& Acar, M. (2020). Critical Audit Matters Within the Perspective of Audit Materiality Threshold: Borsa Istanbul Case. Hacettepe University, Journal of Economics and Administrative Sciences, 38 (2), 185-214.

Altawalbeh, M. A. F. \& Alhajaya, M., E., S. (2019). The Investors Reaction to the Disclosure of Key Audit Matters: Empirical Evidence from Jordan. International Business Research, 12(3), 50-57.

Arzova, S., B. \& Şahin, B., Ş. (2020). ISA 701 (BDS 701) ISA 701 (BDS 701) Key Audit Matters: Analysis For the Financial Institutions in the BIST 30, BIST 50 and BIST 100 Indices. Accounting and Auditing Review, (60), 75-94.

Asbahr, K. \& Ruhnke, K. (2019). Real Effects of Reporting Key Audit Matters on Auditors' Judgement and Choice of Action. International Journal of Auditing, 23(2), 165-180.

Aytaç, A. \& Gücenme G., Ü. (2020). Key Audit Matters: A Perpective Based on Bibliometric Analysis. The World of Accounting Science, 22(3), 547-562.

Bedard, J., Gonthier-Besacier N. \& Schatt, A. (2014). "Costs and Benefits of Reporting Key Audit Matters in the Audit Report: The French Experience", International Symposium on Audit Researh (pp. 5-21). Maastricht: ISAR-International Symposium on Audit Researh. https://www.isarhq.org/2014_downloads/papers/ISAR2014_Bedard_Besacier_S chatt.pdf.

Biçer, A. \& Erol, S. (2017). Communicating Key Audit Matters Identified During Audit Process to Financial Information Users in Accordance with ISA 701, Marmara Üniversitesi Öneri Dergisi, 12(47), 71-84.

Ciğer, A., Vardar, G. Ç. \& Kınay, B. (2019). Key Audit Matters: A Research on Listed Firms in CEE Countries and Turkey. Business and Economic Horizons, 15(3), 393-422.

Ciğer, A., Vardar, G. Ç. \& Kınay, B. (2019). The Analysis of Key Audit Matters in Independent Auditors' Reports: The Case of Borsa Istanbul, Mali Çözüm Dergisi, 29(153), 109-148.

Çağıran K., F. (2019). BDS 701 Analysis of Key Audit Matters within The Scope of ISA 701 in The Context Of Countries. International Journal of Accounting and Finance Researches, 1(2), 157-167. 
Çă̆ıran K., F. \& Varıcı, İ. (2018). Key Audit Matters within the Framework of ISA 701: An Analysis on Audit Reports of Companies Listed in BIST Manufacturing Industry. International Journal of Economic and Administrative Studies, (22), 193-208.

Doğan, A. (2018). A New Approach in Auditing: Key Audit Matters, The World of Accounting Science Mart; 20(1); 65-89.

Dow, B. (2014), Proposed Disclosure of Critical Audit Matters. The Corporate Governance.

Ertan, Y. \& K1zık, E. (2019). Key Audit Matters: Investigation of BIST Manufacturing Companies 2017 Audit Reports. Journal of Accounting and Finance, 263-278.

Gold, A., Heilmann, M., Pott, C. \& Rematzki, J. (2020). Do Key Audit Matters Impact Financial Repoting Beavior? International Journal of Auditing, 1-13.

Gökgöz, A. (2018). (Reporting Key Audit Matters within the Independent Audit's Report and A Study on The Companies Listed in Istanbul Stock Exchange. Journal of Accounting, Finance and Auditing Studies, 4(2), 126-138.

Gönen, S. \&Yıldırım, F. (2019). ISA 701 Key Audit Matters: An Examination for Banks and Insurance Companies Enlisted in BIST. Congress of International Applied Social Sciences, 04-06 April, İzmir, Turkey.

In, C., Kim, T. \& Park, S. (2020). Key Audit Matters for Production-To-Order Industry and Conservatism. International Journal of Financial Studies, 8(5), 1-19.

İşseveroğlu, G. (2019). Key Audit Matters in Independent Audit Report: Analysis on Insurance Companies Listed in The BIST in 2017 and 2018, Journal of Accounting and Finance, (84): 49- 64.

Karacan, S. \& Uygun, R. (2016) Notification of the Independent Auditor's Report Audit of Key Matters - Ias 701. The Journal of International Social Research, 11(57), 632-549.

Kavut, F., L. \& Güngör, N. (2018). Key Audit Matters in Independent Audit: An Analysis on Firm Listed In The Bist-100 in 2017, Journal of Accounting Institute, 16(59), 59-70.

Keskin, D. A., Tutar, S., Öktem, B. \& Akçay, B. (2020). The Effect of Gender on The Readability of Key Audit Matters According to ARI Readability Index: A Sectoral Review. Marmara Üniversitesi Öneri Dergisi, 15(53), 209-228.

Köhler, A., Ratzinger-Sakel, N. \& Theis, J. (2020). The Effects of Key Audit Matters on the Auditor's Report's Communicative Value: Experimental Evidence from Investment Professionals and Non-professional Investors. Accounting in Europe, 17(2), 105-128.

Oktay, S., Bokurt, S. \& Şahin, B., Ş. (2018). Investigation of Studies in the Field of Key Audit Matters by Content Analysis. International Journal of Tourism, Economic and Business Sciences, 2(2), 322-327.

Public Company Accounting Oversight Board Interim Auditing Standards, AU Section 230.11, Due Professional Care in the Performance of Work. 
Public Oversight Accounting and Auditing Standarts Authority. (2017) Communicating Key Audit Matters in the Independent Auditor's Report. https://kgk.gov.tr/Portalv2Uploads/files/Duyurular/v2/TDS/TDS_2021_Seti/BD S\%20701.pdf.

Sahyda, R. (2019). Key Audit Matters in Enhanced Auditor's Report: Tracing Malaysia in Its First Year Implementation. International Journal of Progressive Sciences and Technologies, 13(1), 39-45.

Sarısoy, Ö. \& Kepçe, N. (2019). Communicating Key Audit Matters in the Independent Auditor's Report and Expectation Gap. Mali Çözüm, 29(153), 39-66.

Sayar, Z., A., R. \& Ergüden, E., A. (2016), Son Düzenleme ve Gelişmeler Kapsamında Değişecek ve Yenilenecek Bağımsız Denetçi Raporları, Accounting and Auditing Review, 48, 85-98.

Segal, M. (2019). Key Audit Matters: Insight from Audit Experts. Meditari Accountancy Research, 27(3), 472-494.

Shao, X. (2020). Research on Disclosure Status and Influencing Factors of Key Audit Matters. Modern Economy, 11, 701-725.

Sierra-Garcia, L., Gambetta, N., Garcia-Benau, M. A. \& Orta-Perez, M. (2019). Understanding the Determinants of the Magnitude of Entity-Level Risk and Account-Level Risk Key Audit Matters: The Case of the United Kingdom. The British Accounting Review 51, 227-240.

Şen, S. (2003). Hatalı ve Hileli İşlemlerin Tespiti İçin Denetim Teknikleri, Yaklaşım Yayınları.

Taş, O., Mert, H. \& Varcan Başkaya, A. (2019). Key Audit Matters of Independent Audit Reports and A Research on Implementations. Global Business Research Congress, PAP- V.9-2019(31), 155-159

Teraman, Ö. \& Çelik, B. (2019), Reflection of Key Audit Matters on Independent Auditors' Report: The Effect on Auditors, Journal of Cukurova University Economics and Administrative Sciences, 23(1), 49-61.

Uzay, Ş. \& Köylü, Ç. (2018). Key Audit Matters: A Research on Borsa Istanbul, Erciyes University Journal of Faculty of Economics and Administrative Sciences, (52), 47-70.

Uzun Kocamıș, T. \& Yıldırım, G. (2019). Key Audit Issues in the Independent Auditor's Report: Possible Effects. IBAD Journal of Social Sciences. (Special Issue), 634642.

Velte, P. (2018). Does Gender Diversity in The Audit Committee Influence Key Audit Matters' Readability in The Audit Report? Uk Evidence. Corporate Social Responsibility and Environmental Management, 25(5), 748-755. 